\title{
Discovery of $\sim 4.0$ Ga detrital zircons in the Aermantai ophiolitic mélange, East Junggar, northwest China
}

\author{
HUANG Gang $^{1 *}$, NIU GuangZhi ${ }^{1}$, ZHANG ZhanWu $^{1}$, WANG XinLu ${ }^{1}$, XU XueYi ${ }^{2}$, \\ GUO Jun ${ }^{1} \&$ YU Feng ${ }^{1}$
}

\footnotetext{
${ }^{1}$ The Regional Institute of Shaanxi Bureau of Geological Exploration, Xianyang 712000, China;

${ }^{2}$ Xi'an Institute of Geology and Mineral Resource, Xi'an 710054, China
}

Received November 16, 2012; accepted March 22, 2013; published online May 3, 2013

\begin{abstract}
The East Junggar is an important part of the Central Asian Orogenic Belt (CAOB). Using in situ zircon dating and Hf isotopic analysis by LA-ICP-MS and MC-ICP-MS, respectively, a detrital zircon of $\sim 4040$ Ma age was found in sedimentary sequences from the Aermantai ophiolitic mélange, East Junggar. This is the oldest age record in the East Junggar terrane, and also marks the first zircon locality in the CAOB with an age older than $4.0 \mathrm{Ga}$, which is attributed to the Hadean crust. The $4040 \mathrm{Ma}$ detrital zircon has an $\varepsilon_{\mathrm{Hf}}(t)$ value of -5.2 and a two-stage $\mathrm{Hf}$ modal age of $4474 \mathrm{Ma}$, suggesting the presence of very old (Hadean) crustal material in the source area. Beside peak ages of $446 \mathrm{Ma}$, we found four age groups of 3.6-3.1 Ga, 2.53-2.37 Ga, 1.14-0.89 Ga and $0.47-0.42 \mathrm{Ga}$ from 141 effective measuring points. The age of 426 $\pm 4 \mathrm{Ma}$ for the five youngest detrital zircons defines the lower limit of the deposition time of sedimentary sequencess in the Aermantai ophiolitic mélange. The 0.47-0.42 Ga zircons exhibit ${ }^{176} \mathrm{Hf} /{ }^{177} \mathrm{Hf}$ ratios of 0.282156 to 0.282850 , corresponding to variable $\varepsilon_{\mathrm{Hf}}(t)$ values from -9.3 to 12.0 and $\mathrm{Hf}$ model ages from 2011 to $646 \mathrm{Ma}$. These characteristics are similar to those of the early Paleozoic igneous and gneissic zircons from the Altai, but significantly different from those of the East Junggar. Based on the material structures of felspathic greywacke, the morphology, internal texture and age distributions of dated detrital zircons, in combination with a study of the regional geological data, it is suggested that the sedimentary sequences in the Aermantai ophiolitic mélange was deposited in the Late Silurian, with the main provenance from the Altai Orogen in the north. This indicates that the early Paleozoic ocean represented by the Aermantai ophiolitic mélange was readily closed during the Late Silurian, and the northern edge of the East Junggar terrane was accreted to the Altai Orogen. The joint of them then served as a marginal orogen in the southern edge of the Siberia Paleocontinent.
\end{abstract}

East Junggar, Aermantai ophiolitic mélange, Hadean, detrital zircon, zircon U-Pb dating, Hf isotopes

Citation: Huang G, Niu G Z, Zhang Z W, et al. Discovery of 4.0 Ga detrital zircons in the Aermantai ophiolitic mélange, East Junggar, northwest China. Chin Sci Bull, 2013, 58: 3645-3663, doi: 10.1007/s11434-013-5842-y

$\mathrm{U}-\mathrm{Pb}$ dating and $\mathrm{Hf}$ isotope analysis of single detrital zircons from sedimentary rocks has been proven to be a powerful tool for tracing the source regions of sedimentary materials [1-5]. Zircons are able to withstand the effects of weathering, erosion, abrasion, and thermal alteration, and are difficult to destroy during transportation and deposition. Zircons are also abundant in intermediate-acid magmatic and high-grade metamorphic rocks, and thus record crustal magmatic and metamorphic events. As such, combined $\mathrm{U}-\mathrm{Pb}$ dating and $\mathrm{Hf}$ isotope analysis of single zircon grains

*Corresponding author (email: hg1104220@yahoo.cn) not only provides accurate ages, but can also provide insights into the possible source regions and provenance of sedimentary rocks, which can be linked to outcropping rocks and the tectonic evolution of the surrounding geological region [6-8]. In particular, zircon U-Pb age spectra for sedimentary samples provide geochronological constrains on the nature of ancient crustal terranes and also define the lower limit of the sediment deposition age [9-11]. Thus, detrital zircon $\mathrm{U}-\mathrm{Pb}$ dating and $\mathrm{Hf}$ isotope analysis represents an unparalleled tool for the study of the nature and tectonic affinity of orogenic belts, as well as linking the erosion of such belts and the formation of sedimentary basin 
sequences $[12,13]$.

Understanding the formation and early evolution of the Earth is an enduring challenge for researchers in the Earth Sciences. Some of the key scientific issues include the age of the earliest continental crust, the nature of this crust, and whether crust-mantle recycling occurred on the early Earth [14]. Rocks with Hadean ages (4.56-3.85 Ga) are rarely preserved today due to the intense modification of the Earth's surface by tectonism and erosion throughout Earth's history $[15,16]$. To date, crustal rocks with ages older than $3.8 \mathrm{Ga}$ have only been found in Greenland $[17,18]$, Canada [19,20], northeastern China [21-23], and eastern Antarctica [24-26]. The Acasta Gneiss from the Wopmay Orogen in Canada, with an age of $\sim 4016 \mathrm{Ma}$, represents the oldest rocks that have been found on Earth [27]. Although very few rock suites that were produced during the earliest stages of the Earth have been discovered, abundant old zircons $(\geqslant 3.8 \mathrm{Ga})$ are present in younger geological units worldwide [28]. These include the northeastern Bavaria region of Germany [29], northern Wyoming in the USA [30], the Yilgarn craton of Western Australia [31], the San Francisco craton of Brazil [32], the high Himalayan region of western Nepal [33], and the Central Asian Orogenic Belt (CAOB) in northern Kazakhstan [34]. Detrital zircons with ages $>4.0 \mathrm{Ga}$ have been discovered in the Jack Hills region of the Yilgarn craton, western Australia, and the oldest zircon thus far dated has an age of $\sim 4.4 \mathrm{Ga}$ [31]. Recently, significant advances have been made in the search for extremely old rocks in China. Since the discovery of tonalite-trondhjemite-granodiorite (TTG) rocks with ages of $3.8 \mathrm{Ga}$ in the Anshan area at the end of the last century, many areas have been shown to contain rocks with detrital zircons that yield ages $>3.8 \mathrm{Ga}$, including Qianxi in Hebei Province [14,35-37], Pulan in the Tibet Autonomous Region [38,39], Yichang in Hubei Province [40], Liadang in Gansu Province [41,42], PingleBeijiang in southeast Guangdong Province [43], and Yushu in Qinghai Province [44]. Particularly notable amongst these studies was the discovery of zircons with ages of 4.1 $\mathrm{Ga}$ in the Pulan area of the Himalayan Orogen in China, and in the Liadang area of the northern Qinling Orogen. These $\geqslant 3.8$ Ga detrital zircons provide an excellent opportunity to further investigate the Earth's oldest crustal rocks and its early evolution.

Herein, we report a detrital zircon U-Pb age as old as $\sim 4040$ Ma from a sedimentary block within the Aermantai ophiolitic mélange, East Junggar, northwest China. This is the oldest zircon age from the East Junggar area, and also marks the first zircon locality in the CAOB to yield a Hadean age.

\section{Geological background and samples}

The Junggar terrane is situated in the central part of the $\mathrm{CAOB}$ and is traditionally divided into the Junggar Basin,
East Junggar terrane, and West Junggar terrane (Figure 1(a)). The area studied in this paper is located in the centralnorthern part of the East Junggar terrane, and lies at the northeastern edge of the Junggar Basin. The East Junggar terrane is considered to be a Phanerozoic accretionary orogen, which is divided into the Altai Orogen to the north by the Irtysh fault zone and the Junggar Basin and Tianshan Orogen to the south by the Kalamaili fault zone [46,47]. Tectonically, the East Junggar terrane comprises, from north to south, the Dulate composite island arc, the Aermantai ophiolite mélange belt, the Yemaquan composite island arc, the Kalamaili ophiolite mélange belt, and the Jiangjunmiao accretionary complex. Due to its complex tectonic evolution, the East Junggar terrane and adjacent areas are a current focus of a range of geological studies [48-53].

The Aermantai ophiolitic mélange belt strikes SE-NW and is located in the central-northern part of the East Junggar terrane (Figure 1(b)). The belt extends from the northern slopes of the Beita Mountains near the China-Mongolia border, crosses the northern slopes of the Aermantai Mountains, and continues northwestwards along the Ulungur River to the Zhaheba area, where it is covered by Quaternary aeolian deposits of the Junggar Basin. The total length of the Aermantai ophiolite mélange belt is ca. $130 \mathrm{~km}$. With the exception of sheeted dyke complexes, all the other rock types characteristic of ophiolite sequences are found in this ophiolitic mélange, including serpentinized harzburgites, dunites, pyroxenites, cumulate gabbros, dolerites, pillow basalts, massive basalts, and radiolarian-bearing siliceous rocks. These rock units crop out as tectonically bound slivers or blocks [55]. Banded chromites are occasionally found within the dunite rocks [56]. In addition, in the ophiolitic mélange in the Zhaheba area, Nb-enriched basalts and ultra-high pressure (UHP) rocks typically associated with an intra-oceanic arc have been discovered [57]. The UHP rocks are lherzolites with olivines that contain oriented masses of melted magnetite, garnet pyroxenites that contain high-Si and high-Ti garnets, quartz magnesites, and garnet amphibolites [58-60]. The presence of these rocks suggests that this region was once characterised by the ultra-deep subduction of oceanic crust. Throughout the extent of the belt, the ophiolite is tectonically emplaced above Late Palaeozoic volcano-sedimentary rocks. The northern boundary of the ophiolitic mélange transitions into a northwards-directed thrust belt. SHRIMP zircon U-Pb ages of gabbros and anorthosite granites from the Zhaheba ophiolite are 489 4 [61] and $496 \pm 6 \mathrm{Ma}$ [62] respectively, and $\mathrm{U}-\mathrm{Pb}$ ages of plagiogranites from the Aermantai ophiolite are 503 \pm 7 Ma [63], which appear to constrain the formation age of the ophiolite as being Late Cambrian to Early Ordovician.

This research is focused on sedimentary sequences within the Aermantai ophiolitic mélange. During the early 1990s, the Second Regional Geological Survey Team of the Xinjiang Bureau of Geology and Mineral Resources carried out a 1:50000 regional geological investigation in the Jieledekala 

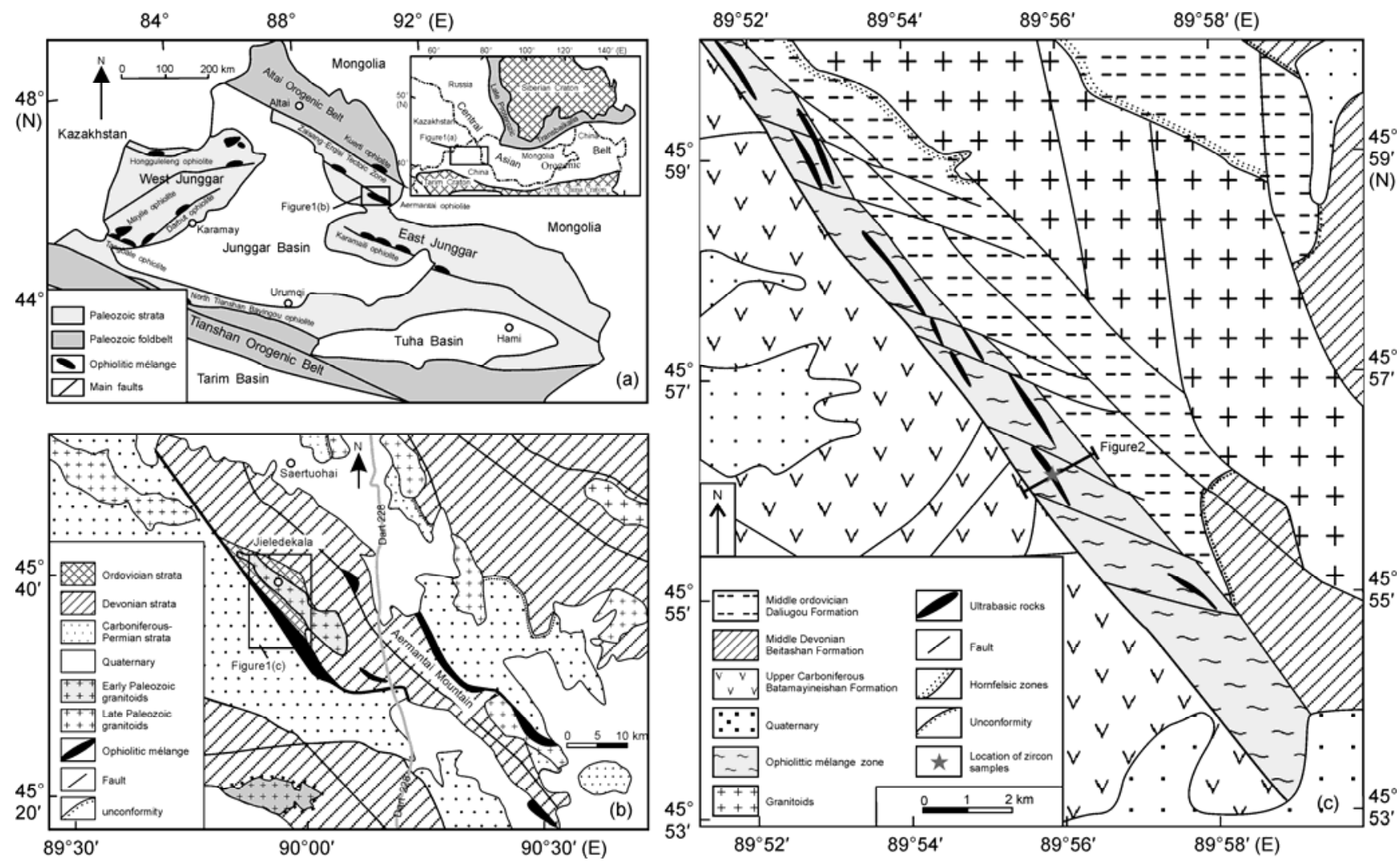

Figure 1 Simplified geological map of the Aermantai ophiolitic mélange and its adjacent areas. (a) Simplified geological map of the Junggar terrane (modified from Chen and Jahn [45]); (b) simplified geological map of the Aermantai area in the East Junggar (modified from Wang et al. [54]); (c) simplified geological map of the Jieledekala area in the East Junggar (modified from 1:50000 ScaleJ ialepakeyizengde Regional Geological Survey Report [64]).

area. This investigation mapped the southern part of the Aermantai ophiolitic mélange, which was named the Jieledekala ophiolitic mélange (Figure 1(c)). This mélange is NW-SE trending, has an outcrop width of ca. $2 \mathrm{~km}$, is separated from the Upper Ordovician Daliugou Formation on the north and the Upper Carboniferous Batamayineishan Formation on the south by faults, and is unconformably overlain by the Middle Devonian Beitashan Formation in the east [64]. Field observations have demonstrated that this ophiolitic mélange contains a range of rock types, including metamorphosed ultramafic rocks (serpentinite), gabbros, diorites, and siliceous rocks. These rock units crop out as lenses or irregular bodies, which are considered the tectonically dismembered sections of an ophiolite sequence. The ultramafic rocks have experienced intense metamorphism and alteration to become serpentinized dunites, serpentinites, and carbonate-rich rocks containing chromium spinel. The ophiolitic mélange also comprises volcanic and sedimentary sequences of various ages, including andesites, andesitic lava breccias, lithic sandstones, feldspathic rock fragment sandstones, and feldspathic greywackes (Figure 2), which represent forearc basin, back-arc basin, and/or continental slope deposits formed during the continent-ocean transition. Inclined and top-thick folds that are affected by ductilebrittle fracturing are widely developed throughout the ophi- olitic mélange. The matrix of the mélange consists mainly of foliated fine-grained clastic and cataclastic rocks. A zircon $\mathrm{U}-\mathrm{Pb}$ age of $508 \pm 4 \mathrm{Ma}$ has been obtained from a meta-gabbro in the mélange. Considerable debate exists as to the age of the sedimentary sequences in the mélange, with published ages ranging from Middle Devonian [65-67] to Middle Ordovician [54,64]. Due to the lack of biostratigraphic and isotopic constraints, the age of the sedimentary blocks in the mélange is based on regional stratigraphy. The sample used in this study was obtained from a sandstone block in the mélange $\left(45^{\circ} 56^{\prime} 04.2^{\prime \prime} \mathrm{N}, 89^{\circ} 55^{\prime} 54.8^{\prime \prime} \mathrm{E}\right)$, which is separated from the southern meta-ultramafic rocks (serpentinites) and the northern lithic sandstones by high-angle faults (Figure 2). The sample is a feldspathic greywacke, greenish to grey in colour, medium- to fine-grained, and layered in units of ca. $15 \mathrm{~cm}$ thickness. Petrographically, the rock consists of detrital material $(60 \%-65 \%)$ and interstitial material $(30 \%-35 \%)$. The detrital grains are mainly poorly sorted and angular quartz $(30 \%-35 \%)$ and feldspar $(25 \%-$ $30 \%$ ), with a typical grain size of ca. $0.15-0.30 \mathrm{~mm}$. The interstitial materials are mainly sericite and chlorite, along with lesser amounts of calcite. The rock is matrix-supported and basal cemented, indicating that it has a low textural maturity and that the sediments were the product of a short transportation distance and rapid accumulation. 


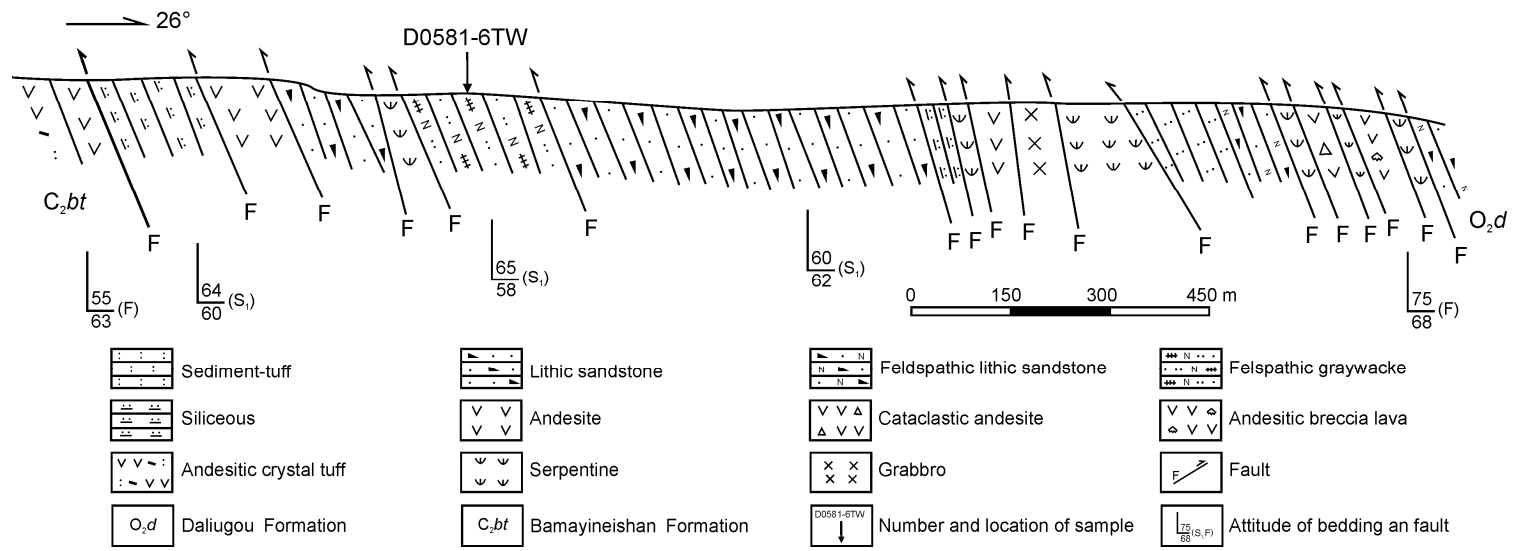

Figure 2 Geologic section of the Aermantai ophiolitic mélange.

\section{Analytical methods}

\subsection{Sample preparation}

Separation of zircon grains was conducted in the No. 203 Research Institute of Nuclear Industry, Xianyang, China, using conventional techniques, including heavy liquids, magnetic separation, and hand-picking under a binocular microscope equipped with ultraviolet light. Zircon grains were mounted in epoxy discs, polished to expose the zircon grains and then coated with gold. Prior to analytical work, polished surfaces were photographed in transmitted and reflected light to reveal the internal structure of the zircons. To further document the internal structure of the zircons and guide selection of sites for $\mathrm{U}-\mathrm{Pb}$ dating and $\mathrm{Hf}$ isotope analyses, cathodoluminescence (CL) images were obtained with a CAMECA electron microprobe at the Institute of Geology and Geophysics, Chinese Academy of Sciences, Beijing, China. The acceleration voltage during CL imaging was $15 \mathrm{kV}$.

\subsection{Zircon U-Pb dating}

Zircon U-Pb dating was carried out with an Agilent 7500 a inductively coupled plasma-mass spectrometer (ICP-MS) coupled to a $193 \mathrm{~nm}$ laser at the Key Laboratory of Continental Collision and Plateau Uplift, Institute of Tibetan Plateau Research, Chinese Academy of Sciences (LCPU), Beijing, China and at the State Key Laboratory of Continental Dynamics (LCD), Northwest University, Xi'an, China. At LCPU, Plesovice [68] and Qinghu [69] natural zircons were used as matrix-matched, external standards for $\mathrm{U}-\mathrm{Pb}$ dating and the NIST SRM612 glass was used as an external standard for trace element analysis. Analyses of Plesovice, Qinghu, and NIST SRM612 were made following every five sample analyses. At LCD, 91500 and GJ-1 natural zircons were used as external standards for $\mathrm{U}-\mathrm{Pb}$ dating and the NIST SRM610 glass was used as an external standard for trace element analysis. Analyses of 91500,
GJ-1, and NIST SRM610 were made following every six sample analyses. Isotope ratios and trace element concentrations were calculated off-line by GLITTER (Ver4.0, Macquarie University). Common $\mathrm{Pb}$ corrections and samples ages were calibrated and calculated using $\mathrm{ComPb}$ Corr\#3.17[70]. U-Pb concordia diagrams, weighted mean age calculations, and $\mathrm{U}-\mathrm{Pb}$ age probability density plots were made using Isoplot/Ex_ver 3 [71].

\subsection{Zircon Lu-Hf isotope analysis}

Hf isotope analyses of zircon were carried out at LCD using a $\mathrm{Nu}$ Plasma high-resolution, multiple-collector ICP-MS (Wrexham, UK) coupled to a Geolas 2005 laser ablation system equipped with a $193 \mathrm{~nm}$ ArF excimer laser. Zircons were ablated with a spot size of $32 \mu \mathrm{m}$, repetition rate of 10 $\mathrm{Hz}$, and energy of $10 \mathrm{~J} / \mathrm{cm}^{2}$. The Hf isotope analytical procedures are similar to those described by Yuan et al. [72]. The isobaric interference of ${ }^{176} \mathrm{Lu}$ on ${ }^{176} \mathrm{Hf}$ was corrected by measuring interference-free ${ }^{175} \mathrm{Lu}$ and using a ${ }^{176} \mathrm{Lu} /{ }^{175} \mathrm{Lu}$ ratio of 0.02669 [73]. Similarly, the interference of ${ }^{176} \mathrm{Yb}$ on ${ }^{176} \mathrm{Hf}$ was corrected by measuring interference-free ${ }^{172} \mathrm{Yb}$ and using a ${ }^{176} \mathrm{Yb} /{ }^{172} \mathrm{Yb}$ ratio of 0.5886 [74]. Time-dependent drifts of $\mathrm{Lu}-\mathrm{Hf}$ isotopic ratios were corrected using a linear interpolation method and interspersed analyses of 91500 zircon. ${ }^{176} \mathrm{Hf} /{ }^{177} \mathrm{Hf}$ ratios obtained for the zircon standards were $0.282295 \pm 27(91500 ; n=17 ; 2 \sigma)$ and $0.282049 \pm 23$ $(\mathrm{GJ}-1 ; n=10 ; 2 \sigma)$. These standard results are in good agreement with the recommended ${ }^{176} \mathrm{Hf} /{ }^{177} \mathrm{Hf}$ ratios for these standards $(0.2823075 \pm 58 ; 0.282015 \pm 19)[75,76]$. The ${ }^{176} \mathrm{Lu}$ decay constant and chondritic ${ }^{176} \mathrm{Hf} /{ }^{177} \mathrm{Hf}$ and ${ }^{176} \mathrm{Lu} /$ ${ }^{177} \mathrm{Hf}$ ratios used in our calculations are $1.865 \times 10^{-11} \mathrm{y}^{-1}$ [77], 0.282772, and 0.0332 [78], respectively. Single-stage model ages $\left(T_{\mathrm{DM} 1}\right)$ were calculated relative to depleted mantle with present-day ${ }^{176} \mathrm{Hf} /{ }^{177} \mathrm{Hf}=0.28325$ and ${ }^{176} \mathrm{Lu} /{ }^{177} \mathrm{Hf}$ $=0.0384$ [79]. Two-stage model ages $\left(T_{\mathrm{DM} 2}\right)$ were calculated by assuming a mean ${ }^{176} \mathrm{Lu} /{ }^{177} \mathrm{Hf}$ value of 0.015 for average continental crust [80]. Initial ${ }^{176} \mathrm{Hf} /{ }^{177} \mathrm{Hf}$ ratios and $\varepsilon_{\mathrm{Hf}}(t)$ values were calculated using zircon U-Pb ages. 


\section{Results}

\subsection{Zircon CL images}

Zircons from the feldspathic greywacke sample D0581$6 \mathrm{TW}$ are pale pink or pink (ca. 5\% are deep pink), transparent to translucent, and are mostly $70-170 \mu \mathrm{m}$ in size. The internal structure and shape of the zircons allows them to be divided into two groups. The first group of zircons are mostly euhedral to subhedral and sub-angular (Figure 3(a)), which implies that these zircons have had a short transportation distance. Most zircons in this group exhibit zoning that is characteristic of magmatic crystallization. The second group of zircons are mostly subhedral to anhedral, but well rounded (Figure 3(b)-(d)), implying that these zircons have undergone long transportation distances. A small number of zircons in this second group have distinct cores and overgrown rims with variable widths, indicating metamorphism prior to transportation and deposition.

\subsection{Zircon $\mathrm{U}-\mathrm{Pb}$ ages}

For zircon ages $>1000 \mathrm{Ma}$, we adopted the ${ }^{207} \mathrm{~Pb} /{ }^{206} \mathrm{~Pb}$ age, and for ages $<1000 \mathrm{Ma}$ we adopted the ${ }^{238} \mathrm{U} /{ }^{206} \mathrm{~Pb}$ age. We conducted 148 randomly selected analyses of zircons from sample D0581-6TW, which yielded 141 robust ages from 135 single zircon grains (Table 1). Analyses numbered 1-119 were carried out at LCPU and analyses 120-154 were carried out at LCD. The analyses enclosed by parentheses in Table 1 were not used in the statistical analysis of the data.

A small number of very old detrital zircon ages were obtained from the feldspathic greywacke sample, with the oldest being $>4.0 \mathrm{Ga}$. Two analyses were conducted on this oldest zircon (analyses 32 and 138), yielding ${ }^{207} \mathrm{~Pb} /{ }^{206} \mathrm{~Pb}$ ages of $4043 \pm 5$ and $4040 \pm 5 \mathrm{Ma}$, and $\mathrm{Th} / \mathrm{U}$ ratios of 0.42 and 0.21 , respectively. Both of these analyses are concordant at the 99\% confidence level (Figure 4(a)), suggesting that these two ages are reliable. Petrographically, this zircon
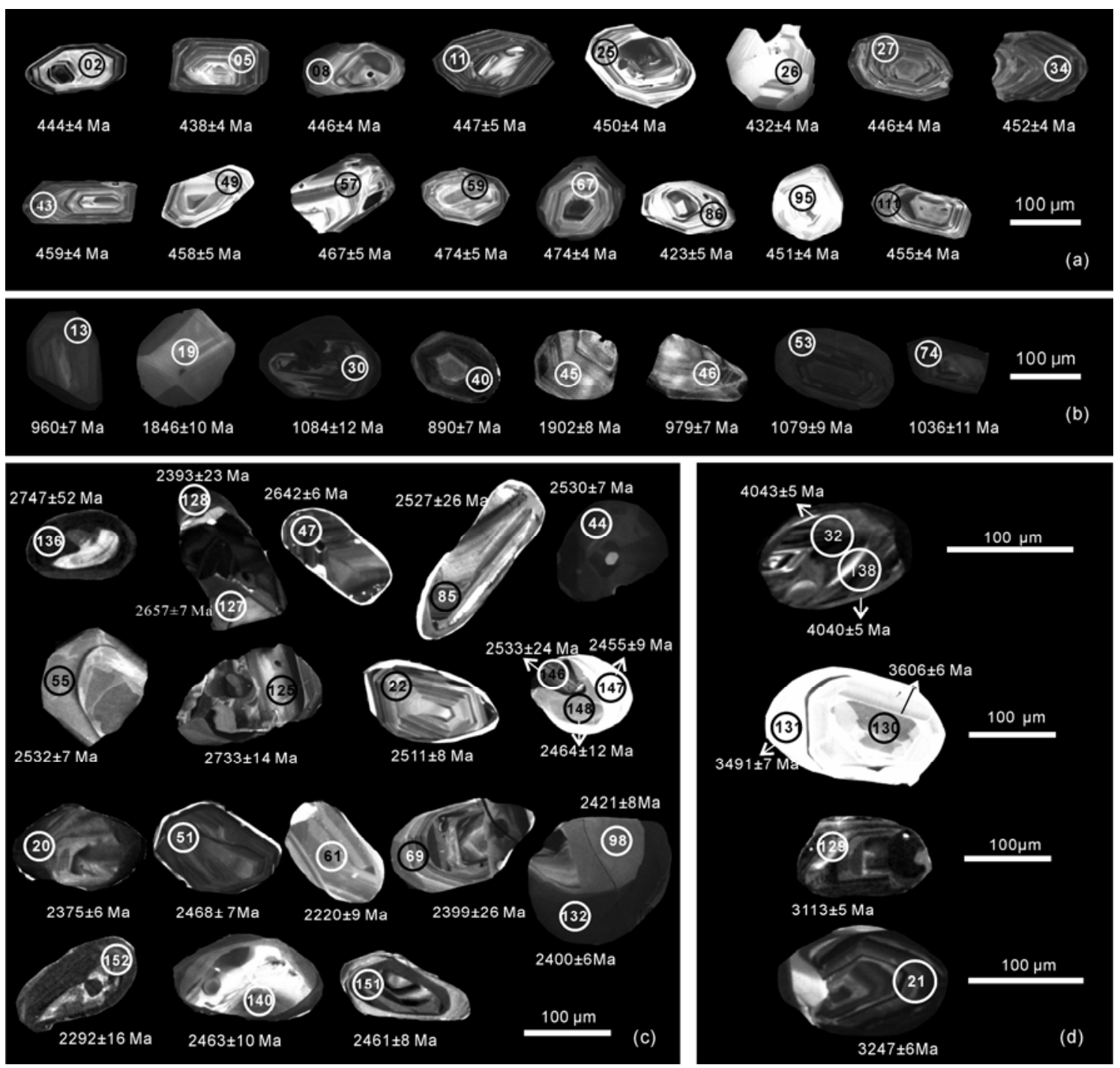

Figure 3 CL images of the detrital zircons with ages (a) <500 Ma, (b) 2000-800 Ma, (c) >3000 Ma and (d) 3000-2000 Ma. 

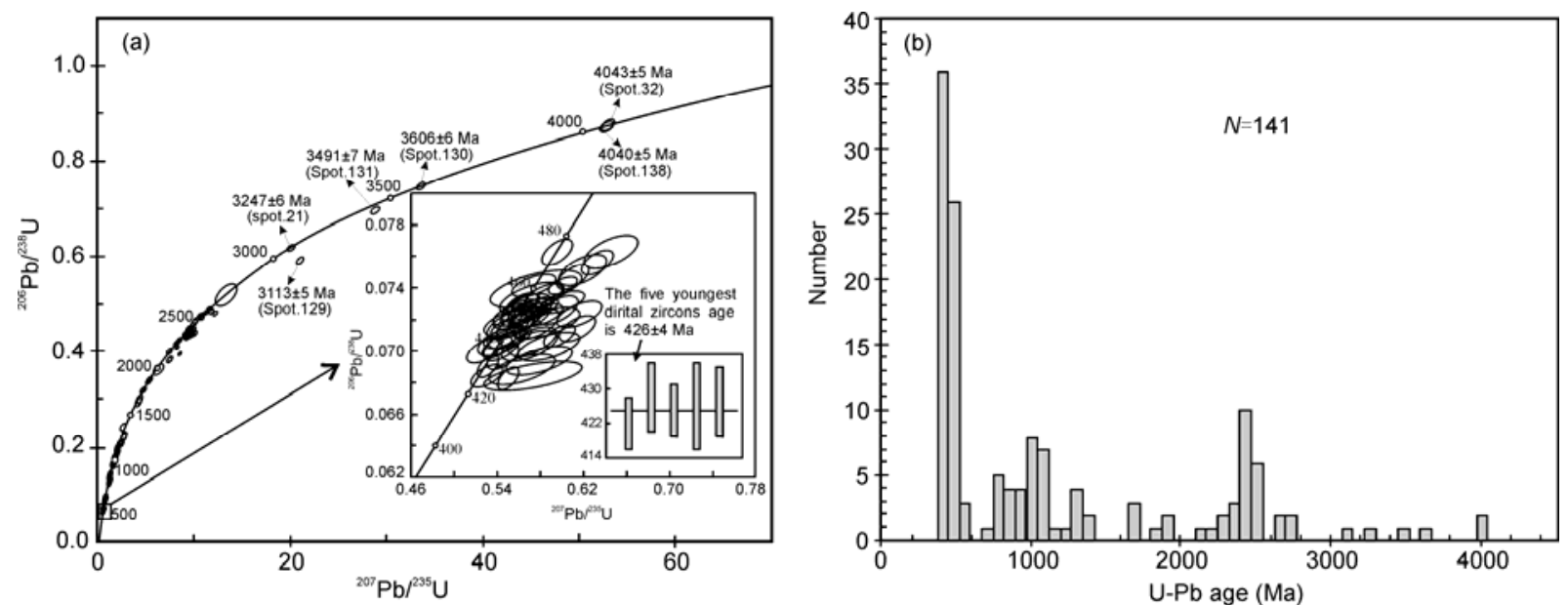

Figure $4 \mathrm{U}-\mathrm{Pb}$ concordia diagrams (a) and frequency chart (b) for detrital zircons from the sedimentary sequences in the Aermantai ophiolitic mélange.

grain is deep pink in colour, semi-transparent, and rounded. CL images show clear core-to-rim zoning in this zircon grain (Figure 3(d)). The inner core is ca. $10-15 \mu \mathrm{m}$ in diameter and has a few wide and irregular growth bands. The surface of the mantle is slightly uneven, zoned, and has uniformly low CL. The narrow rim has no girdle and shows weak CL. These features and the high $\mathrm{Th} / \mathrm{U}$ ratio suggest that this zircon is probably of magmatic origin. The two $\mathrm{U}-\mathrm{Pb}$ analyses are from the mantle of the grain and, coupled with the age concordancy, indicates that the U-Pb isotope systematics of this zircon have remain closed to later tectonic processes.

Apart from these two U-Pb ages of $>4.0 \mathrm{Ga}$, a number of other old and (nearly) concordant ${ }^{207} \mathrm{~Pb} /{ }^{206} \mathrm{~Pb}$ ages of $3606 \pm$ 6 to $3113 \pm 5 \mathrm{Ma}$ were obtained (analyses 21, 129-131). Analyses 130 and 131 were obtained from the core and rim of the same zircon grain. CL images show that this zircon grain has well-developed core-to-rim zoning (Figure 3(d)), with a dark grey and unzoned inner core that has a high $\mathrm{Th} / \mathrm{U}$ ratio (1.10). The mantle is weakly zoned and shows characteristics typical of a magmatic origin. The rim is white, has growth bands of variable width, exhibits no zoning, and has a low $\mathrm{Th} / \mathrm{U}$ ratio (0.34). These features are typical of metamorphic zircon. The different ${ }^{207} \mathrm{~Pb} /{ }^{206} \mathrm{~Pb}$ ages of the core and rim probably represent at least two tectono-thermal events. ${ }^{207} \mathrm{~Pb} /{ }^{206} \mathrm{~Pb}$ ages of analyses 21 and 129 are $3247 \pm 6$ and $3113 \pm 5 \mathrm{Ma}$, respectively, with $\mathrm{Th} / \mathrm{U}$ ratios of 0.48 . CL images show that these zircons have zoning typical of magmatic crystallization (Figure 3(d)).

A zircon U-Pb concordia diagram (Figure 4(a)) and age frequency plot (Figure 4(b)) show three main ages groups: $2.53-2.37,1.14-0.89$, and $0.47-0.42 \mathrm{Ga}$. The youngest group are the most abundant and includes 57 of the 141 robust $\mathrm{U}-\mathrm{Pb}$ ages (ca. $40 \%)$. The peak age of this group is $446 \mathrm{Ma}$, and $\mathrm{Th} / \mathrm{U}$ ratios vary between 0.46 and 1.33 . The average age of the five youngest detrital zircons is $426 \pm 4$ Ma. CL images show that the majority of these zircons are sub-angular and have obvious zoning (Figure 3(a)). All these characteristics are indicative of derivation from a nearby source area with a short transportation distance. The group with ages of 1.14-0.89 Ga has no obvious age peak, and represents a total of 23 ages (ca. 16\%). Zircons in this age group are mostly sub-rounded, although a small number of grains are rounded. The cores of most of these zircons exhibit oscillatory zoning, and a small number of grains have obvious rims of variable width. $\mathrm{Th} / \mathrm{U}$ ratios of these zircons vary from 0.02 to 1.76 (Figure 3(b)). The third group of zircons with ages of 2.53-2.37 Ga comprises 19 ages (ca. 14\%). The age peak of this group is ca. $2.46 \mathrm{Ga}$ and these zircons have $\mathrm{Th} / \mathrm{U}$ ratios from 0.31 to 2.33 . Most of the zircons in this group are sub-rounded and their internal textures allow them to be further divided into two types: one with thin metamorphic rims with clear zoning, and another with magmatic zoning and weak CL and relatively complex textures (Figure 3(c)).

\subsection{Zircon Lu-Hf isotope data}

Fifty-five Lu-Hf isotope analyses were conducted on 55 zircon grains from sample D0581-6TW (Table 2; Figure 5(a), (b)). All the zircons have low ${ }^{176} \mathrm{Lu} /{ }^{177} \mathrm{Hf}$ ratios (most are $>0.002$ ), indicating little accumulation of radiogenic $\mathrm{Hf}$ after zircon crystallization.

The zircons with ages between 0.47 and $0.42 \mathrm{Ga}(n=24)$ have ${ }^{176} \mathrm{Hf} /{ }^{177} \mathrm{Hf}$ values from 0.282156 to $0.282850, \varepsilon_{\mathrm{Hf}}(t)$ values from -9.3 to +12.0 , and two-stage model ages $\left(T_{\mathrm{DM} 2}\right)$ of 2011-646 Ma. The zircons with ages of 1.14-0.89 Ga $(n$ $=12$ ) have low ${ }^{176} \mathrm{Hf} /{ }^{177} \mathrm{Hf}$ values from 0.281721 to $0.282365, \varepsilon_{\mathrm{Hf}}(t)$ values from -16.8 to +7.8 , and two-stage model ages $\left(T_{\mathrm{DM} 2}\right)$ of $2868-1420 \mathrm{Ma}$. The zircons with ages of $2.53-2.37 \mathrm{Ga}(n=8)$ have low ${ }^{176} \mathrm{Hf} /{ }^{177} \mathrm{Hf}$ values from 0.281104 to $0.281210, \varepsilon_{\mathrm{Hf}}(t)$ values from -7.0 to -0.5 , and two-stage model ages $\left(T_{\mathrm{DM} 2}\right)$ of 3513-3009 Ma, which are much older than the zircon $\mathrm{U}-\mathrm{Pb}$ ages.

One analysis of the $4040 \mathrm{Ma}$ zircon yielded a ${ }^{176} \mathrm{Hf} /{ }^{177} \mathrm{Hf}$ ratio of 0.280084 and $\varepsilon_{\mathrm{Hf}}(t)$ value of -5.2 . The single-stage 


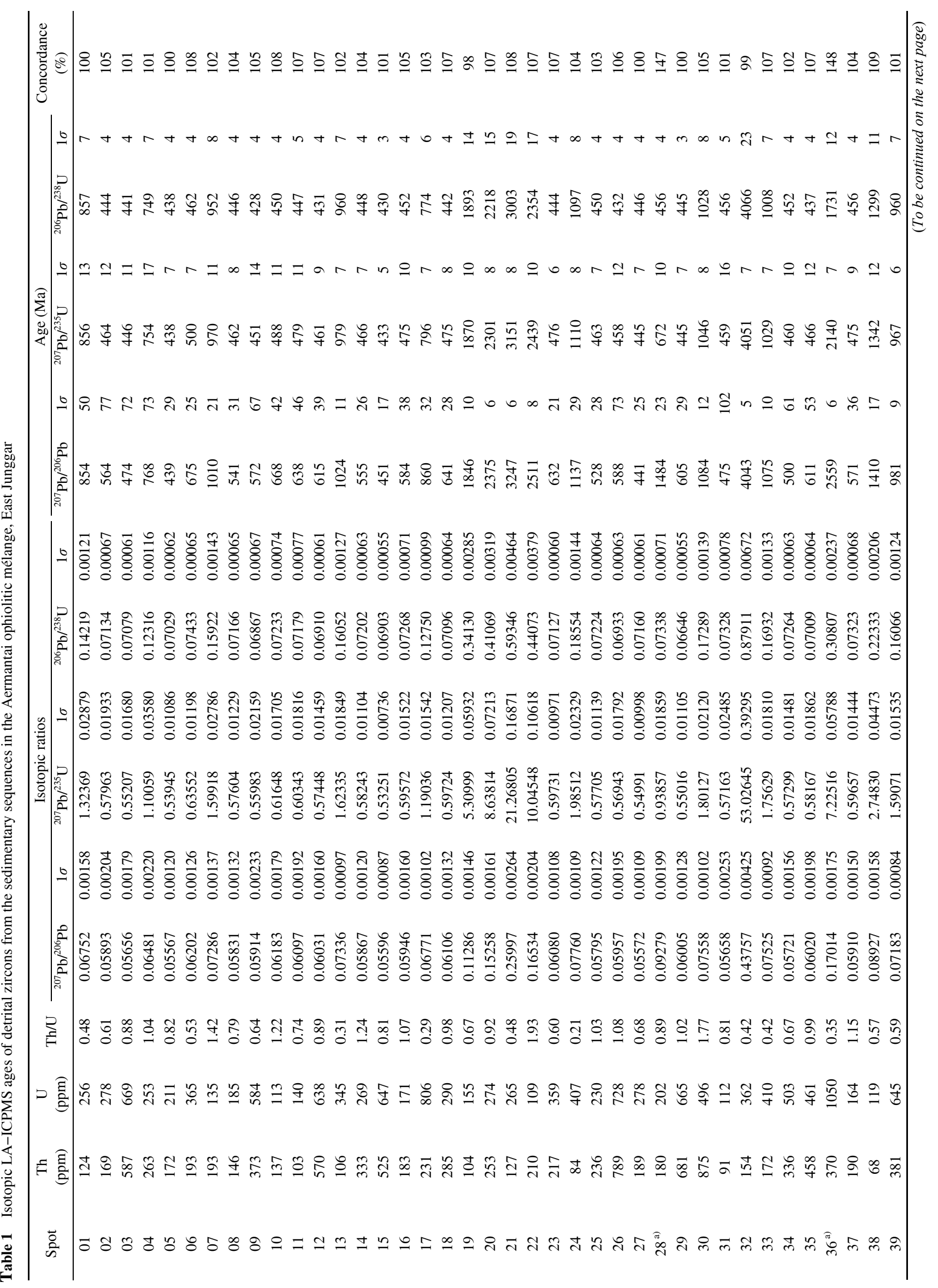




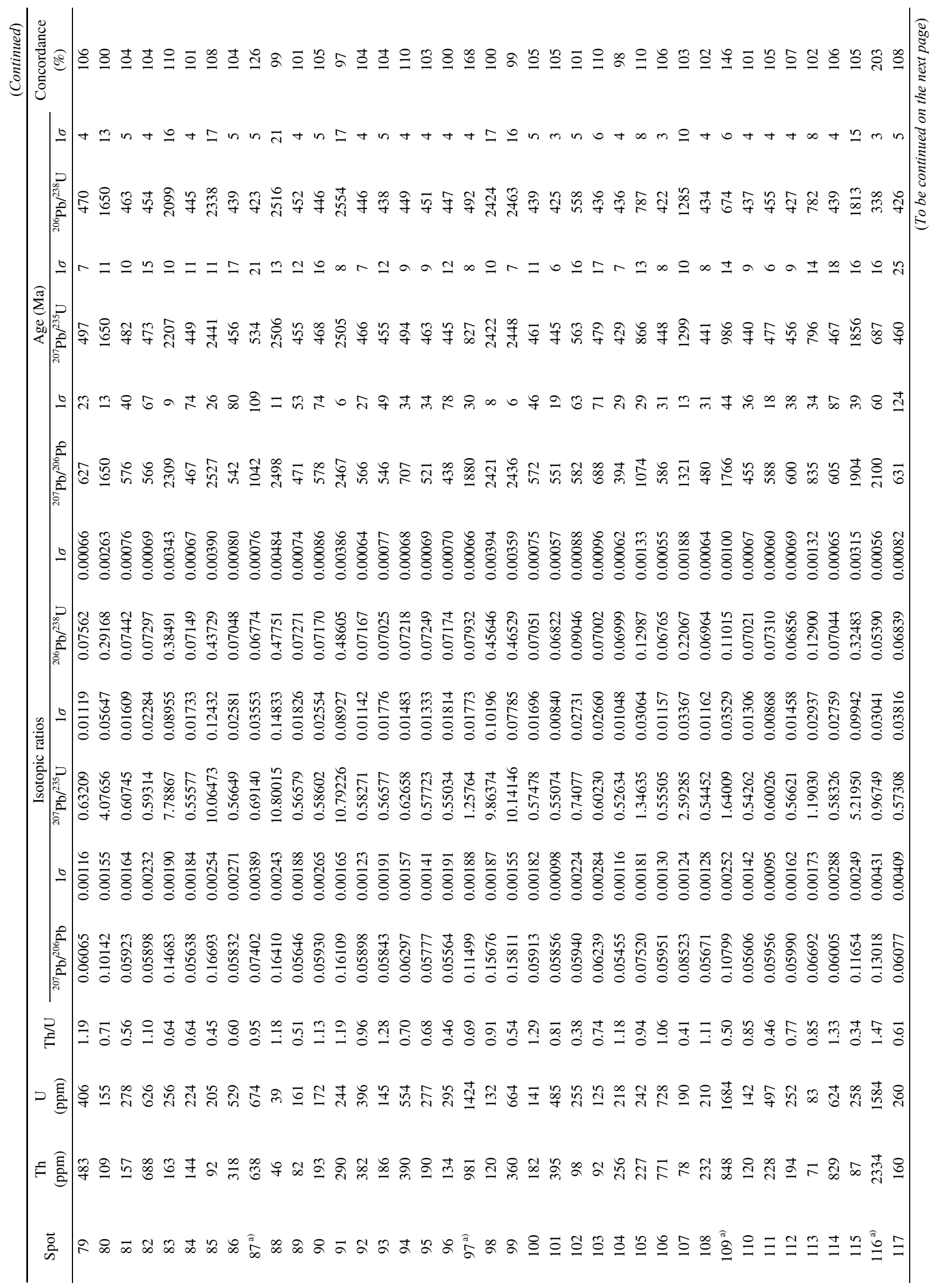




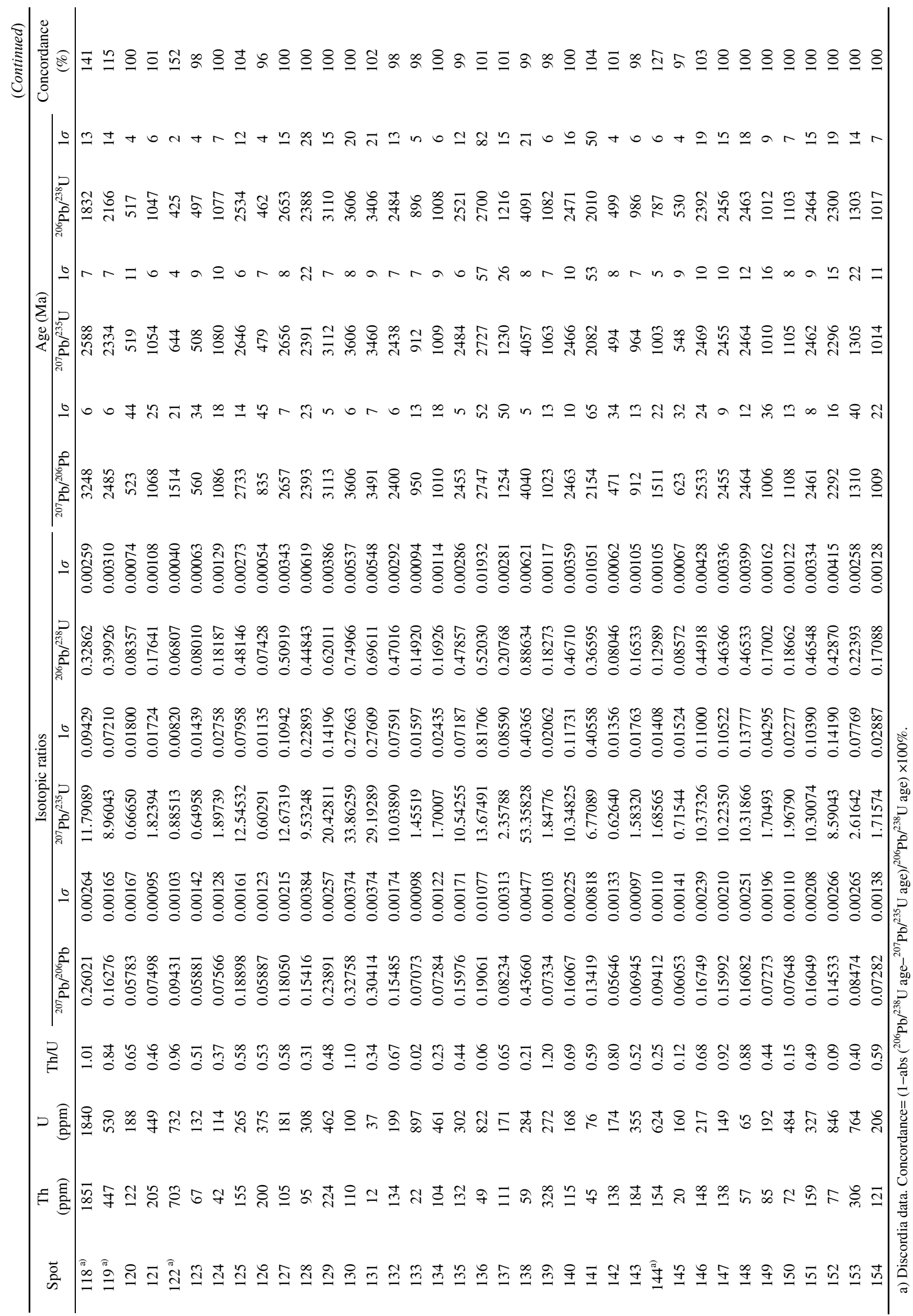




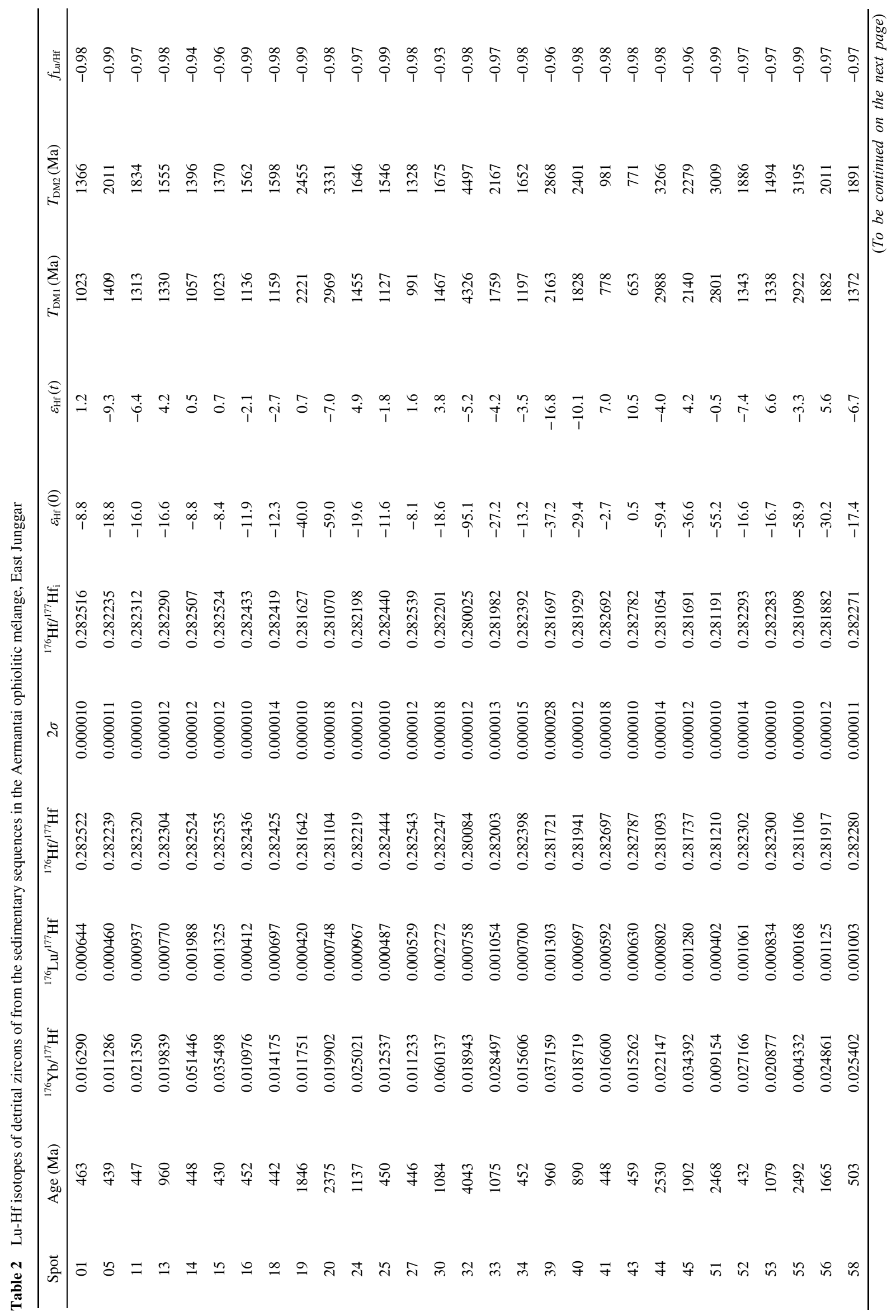



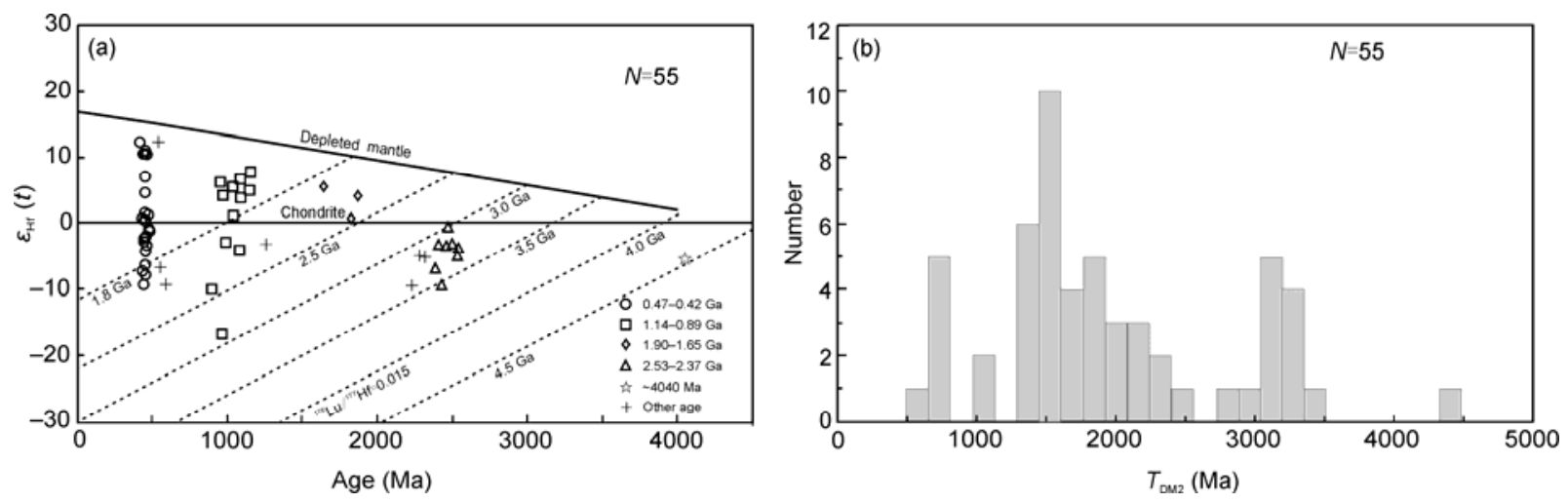

Figure 5 Hf isotopic feature (a) and Hf two-stage model ages histogram (b) of detrital zircons from the sedimentary sequences in the Aermantai ophiolitic mélange.

$\left(T_{\mathrm{DM} 1}\right)$ and two-stage model ages $\left(T_{\mathrm{DM} 2}\right)$ of this zircon are 4326 and $4474 \mathrm{Ma}$, respectively. The $\mathrm{Lu} / \mathrm{Hf}$ ratio $\left(f_{\mathrm{Lu} / \mathrm{Hf}}=\right.$ -0.92 ) of this zircon is much lower than the Lu/Hf ratio of continental crust $\left(f_{\mathrm{Lu} / \mathrm{Hf}}=-0.72 ;[81]\right)$, indicating that the two-stage model age $\left(T_{\mathrm{DM} 2}\right)$ more accurately reflects the age when its source was extracted from the depleted mantle or the average crustal residence age of its source. As such, this old zircon is clearly of Hadean origin. The zircons with ages of $1.90-1.65 \mathrm{Ga}(n=3)$ have ${ }^{176} \mathrm{Hf} /{ }^{177} \mathrm{Hf}$ ratios of 0.281917 to $0.281642, \varepsilon_{\mathrm{Hf}}(t)$ values from 0.7 to 5.6 , and two-stage model ages of 2455-2011 Ma, which indicates that their protolith originated from nascent continental crust.

\section{Discussion}

\subsection{Discovery of 4.0 Ga detrital zircons}

A total of 141 robust detrital zircon U-Pb ages were obtained from the feldspathic greywacke sample, and these range from 4.04 to $0.42 \mathrm{Ga}$. There are five detrital zircons whose $\mathrm{U}-\mathrm{Pb}$ ages are $>3.0 \mathrm{Ga}$, and one concordant zircon has a reliable age of $4.04 \mathrm{Ga}$. The other four old zircons have ${ }^{207} \mathrm{~Pb} /{ }^{206} \mathrm{~Pb}$ ages of $3606 \pm 6,3491 \pm 7,3247 \pm 6$, and $3113 \pm 5 \mathrm{Ma}$. The $4.04 \mathrm{Ga}$ detrital zircon age is the oldest obtained for crustal materials in the East Junggar terrane and the entire CAOB. Hf isotope analysis of this zircon shows that it has a ${ }^{176} \mathrm{Hf} /{ }^{177} \mathrm{Hf}$ ratio of 0.280084 and a $\varepsilon_{\mathrm{Hf}}(t)$ value of -5.2 . The single-stage $\left(T_{\mathrm{DM} 1}\right)$ and two-stage model ages $\left(T_{\mathrm{DM} 2}\right)$ of this ancient zircon are 4326 and $4474 \mathrm{Ma}$, respectively, which are similar to the 4.01-4.37 Ga zircons from the Jack Hills region of Australia [82]. Harrison et al. [82] suggested that Earth's continental crust began to form from ca. 4.4-4.5 Ga, but that this crust was recycled back into the mantle shortly after its formation. The Hf isotope compositions of the Jack Hills zircons are distinct from those of $3.8 \mathrm{Ga}$ zircons in the North China and Yangtze cratons, which have Hf isotopes that are broadly chondritic and model ages of ca. $3.8 \mathrm{Ga}$, showing that they originated from a mantle source that had not experienced significant crust-mantle differentiation. As such, previous studies have suggested that crustal rocks older than $3.8 \mathrm{Ga}$ do not exist in the north China area $[14,83]$. Given that the $>3.0$ Ga detrital zircons have probably experienced one or more transportation and recycling processes before their final incorporation in the sediment, their ultimate original source is difficult to determine. However, the identification of zircon grains with ages $>3.0 \mathrm{Ga}$ in this study and, in particular, the oldest zircon indicates that the East Junggar rocks record the recycling of old, Archaean and Hadean crustal materials. Kröner et al. [34] also dated one inherited zircon with a ${ }^{207} \mathrm{~Pb} /{ }^{206} \mathrm{~Pb}$ age of $3888 \pm 2 \mathrm{Ma}$ from an Early Ordovician diorite porphyry in Stepnya, Kazakhstan, which is part of the western extension of the CAOB.

\subsection{Constraints on depositional age and provenance}

Sedimentary sequences of the Aermantai ophiolitic mélange have youngest detrital zircon U-Pb ages of 0.47 to $0.42 \mathrm{Ga}$. The main age peak is $446 \mathrm{Ma}$ and the weighted average age of the five youngest detrital zircons is $426 \pm 4$ Ma. This age represents the youngest erosional source and also is a lower limit for the sedimentary depositional age. As such, the sedimentary blocks in the Aermantai ophiolitic mélange must have been deposited no earlier than Middle Silurian times and, probably, even later (i.e. Devonian). The percentage of this group of young detrital zircons (Early Palaeozoic) is much higher than that of the old detrital zircons (pre-Early Palaeozoic). $\varepsilon_{\mathrm{Hf}}(t)$ values of the young detrital zircons range from -9.3 to 12.0 and have two-stage model ages of 2011-646 Ma, which are much older than the formation age of the zircons. These young zircons are mostly euhedral or subhedral and angular, implying they have only experienced a short transportation distance. The two groups with older zircon ages of 1.14-0.89 and 2.53-2.37 Ga have $\varepsilon_{\mathrm{Hf}}(t)$ values of -16.8 to 7.8 and -7.0 to -0.5 , respectively, and two-stage model ages $\left(T_{\mathrm{DM} 2}\right)$ of $2868-1420$ and 3513$3009 \mathrm{Ma}$, respectively. The detrital zircons with ages of 2.53 to $2.37 \mathrm{Ga}$ are characterised by negative $\varepsilon_{\mathrm{Hf}}(t)$ values. 
These features highlight the fact that the protolith of the old detrital zircons separated from the depleted mantle and entered the crust during the Archaean crustal accretion event. Most of the detrital zircons from these two older groups are rounded, indicating a relatively long transportation distance. This suggests that the sedimentary sequences in the Aermantai ophiolitic mélange were deposited in an area that experienced intense magmatism and was similar to modern sites of active continental marginal clastic sedimentation.

Recent studies have discovered evidence for Early Palaeozoic magmatism in the eastern Junggar terrane during a 1:25000 regional geological survey and other investigations. For example, we have obtained zircon U-Pb ages for quartz diorite and tonalite in the Yemaquan area that are $443 \pm 6$ and $442 \pm 5 \mathrm{Ma}$, respectively (unpubl. data). Zhang et al. [84] reported a $442 \pm 7 \mathrm{Ma}$ age for a deformed zircon core from a granitic porphyry in the Qiongheba area. In the Versailles area, Du et al. [85] obtained a moyite age of 429 Ma by $\mathrm{U}-\mathrm{Pb}$ zircon dating. However, all these zircons have high
$\varepsilon_{\mathrm{Hf}}(t)$ values and relatively young two-stage model ages (>700 Ma) (Figure 6(a)), which precludes their use in constraining sandstone provenance. Many Early Palaeozoic intrusive rocks are also present in the Harlik Mountains, which is located at the southern edge of the East Junggar terrane. For example, near Harlik Koumenzi, diorite zircon has a U-Pb age of $430 \pm 6 \mathrm{Ma}$ [86], and on the main ridge of the eastern Harlik diorite and granite, zircons have yielded $\mathrm{U}-\mathrm{Pb}$ ages $447 \pm 11$ and $462 \pm 9 \mathrm{Ma}$, respectively [87]. These magmatic rocks are considered to be part of the active continental margin on the southern edge of the Turpan-Hami Basin, which has gradually migrated southwards during the Palaeozoic. The formation of these magmatic rocks is related to the northwards subduction of oceanic lithosphere, which is represented by relict oceanic crust in the Kangguertagg area [88]. Apparently, these tectonic blocks are not a potential provenance source for the sedimentary blocks in the Aermantai ophiolitic mélange. To the north of the studied area, at the southern edge of the Altay region,
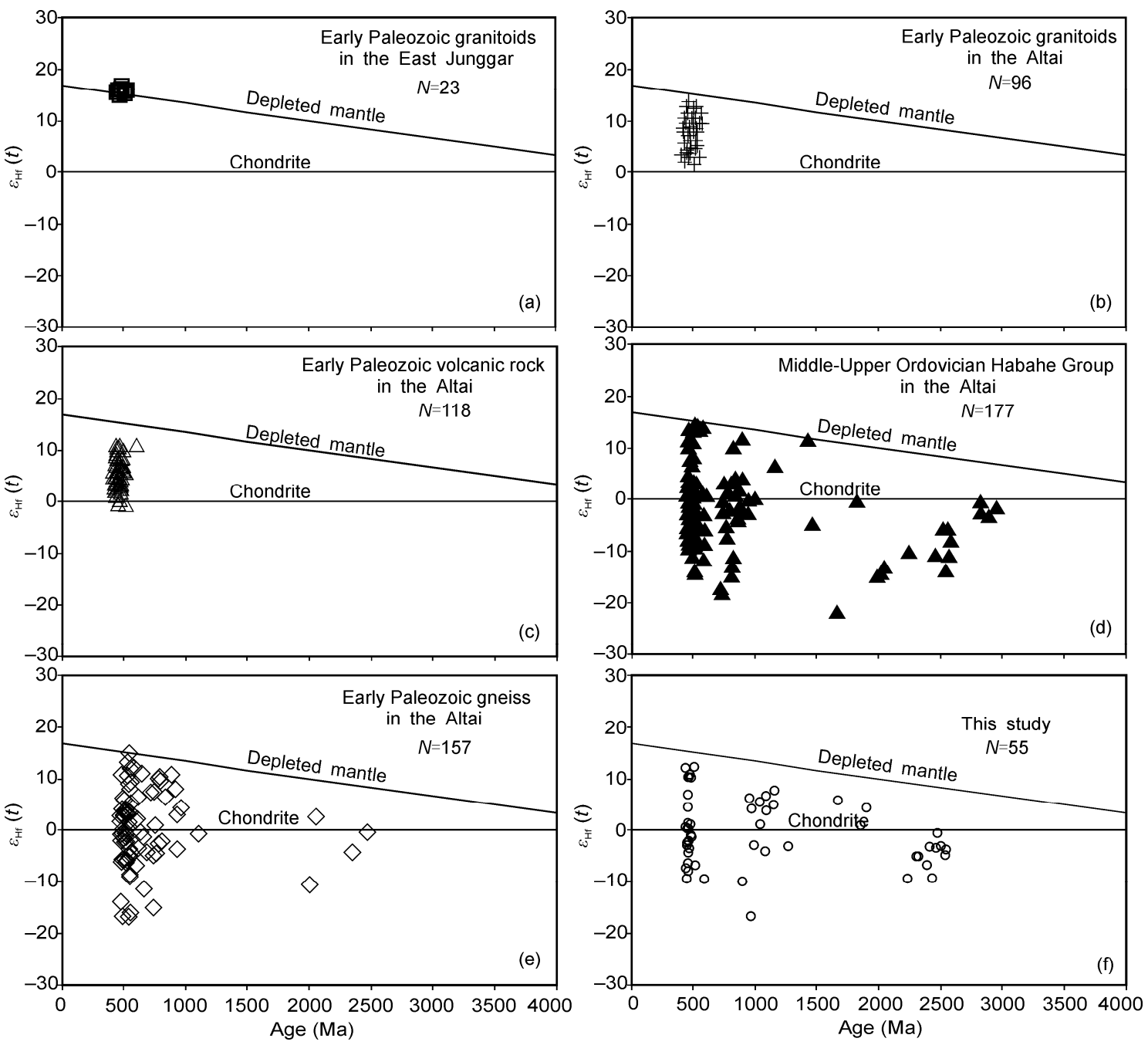

Figure 6 Comparison of probability plots of detrital zircon Hf isotope from the Paleozoic igneous rock and graywackes in the Chinese Altai and East Junggar. Data sources are as follows: (a) from Zhang et al. [84]; (b) from Sun et al. [52] and Cai et al.[97]; (c) from Wang et al. [98]; (d) from Long et al. [96]; (e) from Sun et al. [89]; (f) from this study (data with $>3.6 \mathrm{Ga}$ are excluded). 
Early Palaeozoic granite, volcanic rocks, and gneiss are widely exposed [89-94]. For example, U-Pb ages of rocks in this region are as follows: Qiemurqieke gneissic granites: 462 \pm 10 Ma [90]; Seoul Basin volcanic rocks: 436 \pm 4 Ma [91]; Abagong gneissic syenogranite: 458 \pm 3 Ma [92]; Aergedayi meta-gabbro: 439 $\pm 17 \mathrm{Ma}$ [93]; Kelang Basin biotite granite: $459 \pm 5$ Ma [94]. Recent studies have proposed that these Early Palaeozoic granites and volcanic rocks are subduction-related, syn-orogenic products that formed at an active continental margin [90-95]. Zircon $\varepsilon_{\mathrm{Hf}}(t)$ values and two-stage model ages of these rocks are similar to those of Early Palaeozoic detrital zircons dated in our study (Figure 6(b) and (c)), thus suggesting that the Early Palaeozoic detrital zircons in our sandstone sample may largely originate from the northern Altai Orogen. In terms of Hf isotope composition and the distribution of detrital zircon ages (Figures 6(d), (e), 7(a), (b)), these sedimentary sequences are similar to gneisses of the Upper Ordovician Habahe Group in the Altai Orogen [96]. The sedimentary sequences also have a similar detrital zircon age distribution as the Ordovician Huangcaopo Group in the Yiwu of East Junggar (Figure 7(c)). These relationships indicate that all these units may share a similar provenance, with the provenance of the Ordovician Huangcaopo Group equivalent to the Altai Orogen in the north. This hypothesis is consistent with our results for the detrital zircons from the Aermantai ophiolitic mélange, but inconsistent with the Late Palaeozoic detrital zircon age spectrum of East Junggar (Figure 7(d)), which lies to the north of the Kalamaili ophiolitic mélange. Detrital zircons from East Junggar do not include Precambrian detrital zircon ages, and the provenance is probably from the volcano-sedimentary sequences deposited in the Palaeozoic island arc that once was south of East Junggar [53,99]. Early Palaeozoic and Precambrian detrital zircons have also been found in Carboniferous sandstones to the south of the Kalamaili ophiolitic mélange belt (Figure 7(e)), but its provenance is considered to be from southern areas that are now covered by the Tuha and Junggar basins [100]. In summary, detrital zircons reveal that the provenance of the sedimentary sequences in the Aermantai ophiolitic mélange is the Altai Orogen to the north. Given that the youngest detrital zircon age is $426 \pm 4 \mathrm{Ma}$, it is necessary to refine the depositional age of these sedimentary sequences as being Late Silurian rather than Devonian, as was previously considered to be the case.

\subsection{Palaeozoic tectonic evolution of East Junggar and adjacent areas}

The Aermantai ophiolitic mélange of East Junggar has detrital zircon $\mathrm{U}-\mathrm{Pb}$ ages and $\mathrm{Hf}$ isotope signatures that indicate the sedimentary blocks may have been derived from the Altai Orogen in the Late Silurian. Recent studies have shown that the East Junggar terrane comprises a series of island arc mixtites and an accretionary wedge complex, which were produced by Palaeozoic subduction and accretion
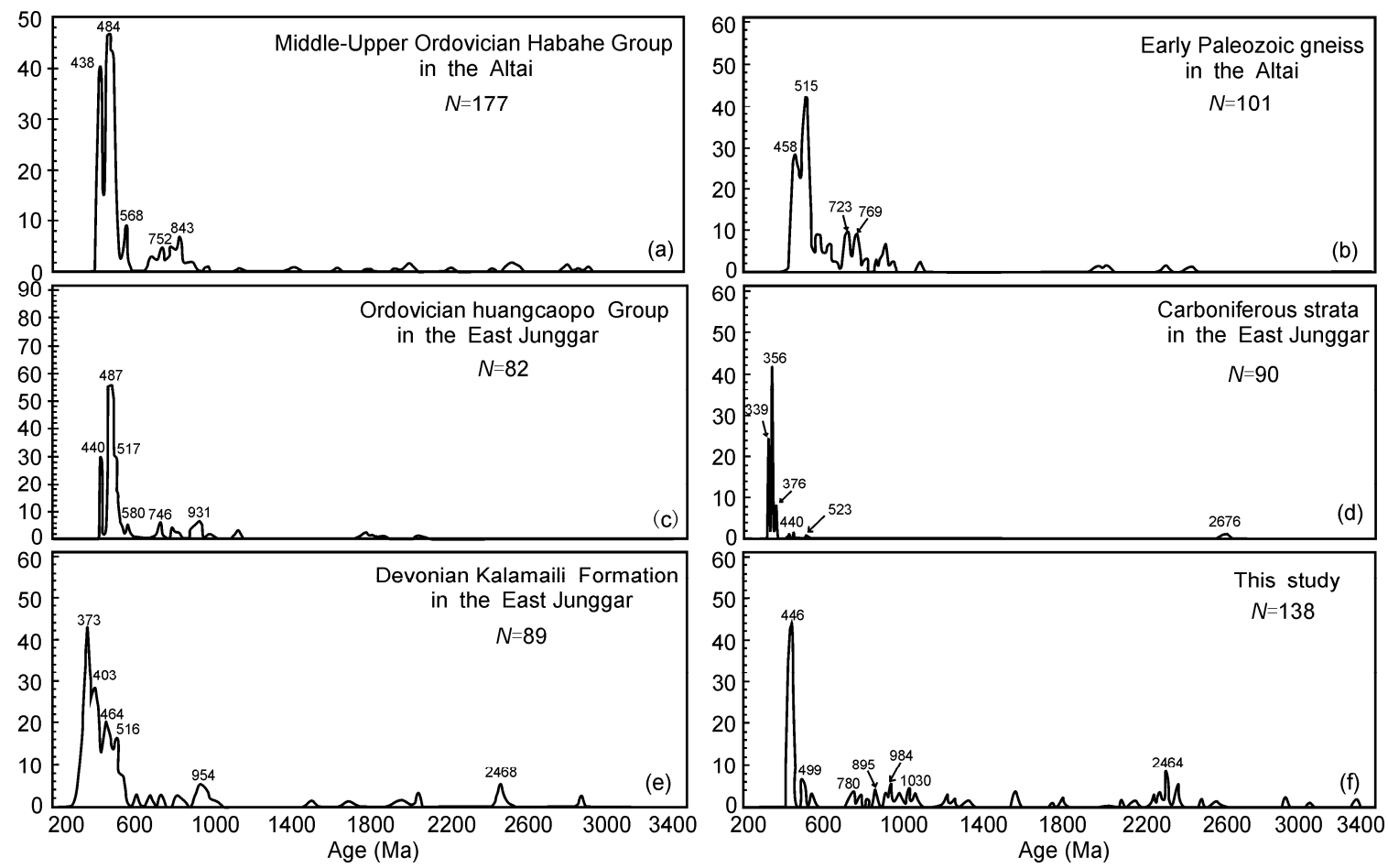

Figure 7 Comparison of probability plots of detrital zircon ages from the Paleozoic graywackes in the Chinese Altai and East Junggar. Data sources are as follows: (a) from Long et al. [53]; (b) from Sun et al. [52]; (c) from Long et al. [96]; (d) from Wang et al. [99]; (e) from Li et al. [100]; (f) from this study (data with $>3.6 \mathrm{Ga}$ are excluded). 
[50,51]. From north to south, the East Junggar terrane is divided into the Dulate composite island arc, the Yemaquan composite island arc, and the Jiangjunmiao accretionary complex. These three tectonic units are separated by the Aermantai and Kalamaili ophiolite belts, which represent Early to Middle Palaeozoic oceanic crust [60,101]. However, the southern edge of the Altai Orogen lies to the north of the Aermantai and Irtysh tectonic belt, where an Early Palaeozoic active continental margin and an acidic magmatic arc were developed. These arc rocks have zircon ages between 470 and $440 \mathrm{Ma}$ [90,95], which are slightly younger than the formation age (505-489 Ma) of the Aermantai supra-subduction zone type ophiolite [60-62]. In the northern part of the East Junggar terrane (Jieledekala area), zircon $\mathrm{U}-\mathrm{Pb}$ ages of quartz diorite and granodiorite are $483 \pm 6$ and $481 \pm 5$ Ma respectively (unpublished data). The Jieledekala granodiorites are products of island arc magmatism, and represent the earliest magmatic event in the Early Palaeozoic. These granodiorites provide strong evidence for the subduction polarity of the oceanic lithosphere. From the Altai Mountains to the south of East Junggar, large-scale thrusts are characterised by oblique southwestwards movements that have overthrust younger rocks to the south $[103,104]$. Broadband seismic data for the East Junggar terrane reveal two strong, north-dipping reflectors at depths of 50 and $100 \mathrm{~km}$ between Kalamaili and Fuyun [104,105]. Moreover, from south Kalamaili to the Altai Mountains, the depth of the Moho gradually increases northwards, and there are bodies with anomalously high $\mathrm{P}$-wave velocities below depths of $18-28 \mathrm{~km}$ that have a thickness of $10 \mathrm{~km}$ and a velocity of $7.3 \mathrm{~km} / \mathrm{s}$, similar to oceanic crust. At the northeastern edge of the Junggar Basin, deposition was continuous from the Middle Silurian to the base of the Lower Carboniferous. The main lithology of these sediments is terrestrial clastic rocks that are interbedded with minor carbonates, which have characteristics typical of passive continental margin deposits.

Based on the lines of evidence presented above, we suggest that the East Junggar Basin was characterised by gradual south-to-north subduction and, during subduction of the oceanic lithosphere, the subduction zone experienced a southward migration. During the Early Ordovician to Middle Silurian, an active marginal magmatic arc formed at the southern edge of the Altai Orogen due to northward subduction of Early Palaeozoic oceanic lithosphere as now represented by the Aermantai ophiolitic mélange. Middle to Late Silurian rocks of the East Junggar terrane are characterised by cold water biota such as Tuvaella fossils [106,107], which only occupied shallow waters at the southern edge of Siberia. Ordovician volcano-sedimentary sequences are unconformably overlain by Middle to Upper Silurian rocks with marine molasse features. These characteristics indicate that the Early Palaeozoic ocean basin system in the East Junggar area had closed by the Middle to Late Silurian and been accreted to the Siberia block to become the southern edge of the Siberia Paleocontinent. However, at this time, the region was still covered by a shallow sea that allowed Tuvaella to migrate across the southern edge of Siberia and reach East Junggar, including the area to the south of the Kalamaili ophiolite belt. Thus, we postulate that the Late Palaeozoic ocean basins located in the Irtysh and southern Mongolia, and the Late Palaeozoic ocean basins located in the southern Kalamaili must have existed within the interior of an enlarged Siberia Paleocontinent due to accretion of the East Junggar terrane. In effect, these ocean basins were underlain by continental crust. Late Silurian sedimentary sequences in the Aermantai ophiolitic mélange were mainly sourced from the Altai Orogen to the north, which shows that during the Late Silurian the northern edge of the East Junggar terrane was already part of the Altai Orogen. This became an integrated marginal orogen at the southern edge of the Siberia Paleocontinent and was the source of the sediments in the Aermantai ophiolitic mélange. Furthermore, the Early Palaeozoic ocean represented by the Aermantai ophiolitic mélange was closed by Late Silurian times.

\section{Conclusions}

(1) We have used LA-(MC)-ICP-MS zircon U-Pb dating to obtain a detrital zircon age spectrum for sedimentary sequences from the Aermantai ophiolitic mélange in East Junggar. The oldest determined zircon age is 4040 Ma. Hf isotope analysis of this zircon indicates that it has negative $\varepsilon_{\mathrm{Hf}}(t)$ and a $\mathrm{Hf}$ isotope two-stage model age that is slightly older than its $\mathrm{U}-\mathrm{Pb}$ age, demonstrating that even older continental crustal materials (Hadean) were present in its source. Other old detrital zircon ages of $3606 \pm 6$ to $3113 \pm 5$ Ma were also obtained. While it is difficult to infer the provenance of the $>3.0 \mathrm{Ga}$ zircons, their ages show that recycling of very old crustal materials with Mesoarchaean, Paleoarchaean, and Hadean ages are recorded by rocks of the East Junggar terrane.

(2) The youngest detrital zircon age is $426 \pm 4 \mathrm{Ma}$ and defines the lower limit of the sediment depositional age. Considering the regional geology, the depositional age of sedimentary sequences in the Aermantai ophiolite mélange is probably Late Silurian.

(3) Detrital zircon U-Pb ages for the sedimentary sequences of the Aermantai ophiolitic mélange largely form three groups at 2.53-2.37, 1.14-0.89, and 0.47-0.42 Ga, with the main age peak being $446 \mathrm{Ma}$. The zircon ages, morphology, and internal structures, and Hf isotope data are consistent with the sedimentary provenance having been to the north in the Altai Orogen. During the Late Silurian, the Early Palaeozoic ocean represented by the Aermantai ophiolitic mélange closed and the northern edge of the East Junggar terrane had accreted to the Altai Orogen, which became an integrated marginal orogen on the southern edge of the Siberia Paleocontinent. 
We thank Profs. Li Jingyi, Wang Yu, Yang Yongcheng and two anonymous reviewers for their constructive and valuable comments. We also thank Yuan Yahui, Wang Houqi, Li Shun and Zhang Jinyu for their help with zircon $\mathrm{U}-\mathrm{Pb}$ dating and $\mathrm{Hf}$ isotope analyses.

1 Pell S D, Williams I S, Chivas A R. The use of protolith zircon age fringerprints in determining the protosource areas for some Australian the dune sands. Sedim Geol, 1997, 109: 233-360

2 Fedo C M, Sircombe K N, Rainbird R H. Detrital zircon analysis of the sedimentary record. In: Hanchar J M, Hoskin P W O, eds. Rev Mineral Geochem, 2003, 53: 277-303

3 Richards A, Argles T, Harris N, et al. Himalayan architecture constrained by isotopic tracers from clastic sediments. Earth Planet Sci Lett, 2005, 236: 773-796

4 Veevers J J, Saeed A, Belousova E A, et al. U-Pb ages and source composition by Hf-isotope and trace-element analysis of detrital zircons in Permian sandstone and modern sand from southwestern Australia and review of the palegeographical and denudational history of the Yilgarn Craton. Earth-Sci Rev, 2005, 68: 245-279

5 Veevers J J, Belousova E A, Saeed A, et al. Pan-Gondwanaland detrital zircons from Australia analysed for Hf-isotopes and trace elements reflect an ice-covered Antarctic provenance of 700-500 Ma age, $T_{\mathrm{DM}}$ of 2.0-1.0 Ga, and alkaline affinity. Earth-Sci Rev, 2006, 76: 135-174

6 Wan Y S, Li R W, Wilde S A, et al. UHP metamorphism and exhumation of Dabie Orogen: Evidence from SHRIMP dating of zircon and monazite from a UHP frantic gneiss cobble form the Heifei Basin, China. Geochimi Cosmochimi Acta, 2005, 69: 4333-4348

7 Wan Y S, Song T R, Liu D Y, et al. Mesozoic monazite in Neoproterozoic metasediments: Evidence for low-grade metamor-phism of Sinian sediments during Triassic continental collision, Liaodong Peninsula, NE China. Geochem J, 2007, 41: 47-55

8 Wan Y S, Liu D Y, Wang W, et al. Provenance of Mesoto Neoproterozoic cover sediments at the Ming Tombs, Beijing, North China Craton: An integrated study of U-Pb dating and $\mathrm{Hf}$ isotopic measurement of detrital zircons and whole-rock geochemistry. Gandwana Res, 2011, 20: 219-242

9 Bernet M, Spiedel C. Detrital thermochronology provenance analysis, exhumation, and landscape evolution of mountain belts. Geol Soc Am Spec Pap, 2004, 378: 1-126

10 Zhou J B, Wilde S A, Zhao G C, et al. SHRIMP U-Pb zircon dating of the Neoproterozoic Penglai Group and Archean gneisses from the Jiaobei Terrance, North China, and their tectonic implications. Precambrian Res, 2008, 160: 323-340

11 Lu S N, Li H C, Chen Z H, et al. Detrital zircon population of Proterozoic meta-sedimentary strata in the Qinling-Qilian-Kunlun Orogen (in Chinese). Acta Petrol Sin, 2009, 25: 2195-2208

12 Li R W, Wan Y S, Cheng Z Y, et al. Provenance of Jurassic sediments in the Heifei Basin, east-central China and the contribution of high-pressure and ultrahigh-pressure metamorphic rocks from the Dabie Shan. Earth Planet Sci Lett, 2005, 231: 279-294

13 Zhou J B, Wilde S A, Zhao G C, et al. SHRIMP U-Pb zircon dating of the Wulian Complex: Defining the boundary between the North and South China Cratons in the Sulu Orogenic Belt, China. Precambrian Res, 2008, 162: 559-576

14 Wu F Y, Yang J H, Liu X M, et al. Hf isotopes of the $3.8 \mathrm{Ga}$ zircons in eastern Hebei Province, China: Implications for early crustal evolution of the North China Craton. Chin Sci Bull, 2005, 50: 1996-2003

15 Gradstein F M, Ogg J G, Smith A G, et al. A new geologic time scale, with special reference to Precambrian and Neogene. Episodes, 2004, 27: $83-100$

16 Lu S N, Wang H C, Li H K. Unscramble the ISC 2004 and special reference to Precambrian from 2004 to 2008 (in Chinese). J Stratig, 2005, 25: 180-187

17 Kinny P D. 3820 Ma zircons from tonalitic Amitsoq gneiss in the Godthab district of southern West Greenland. Earth Planet Sci Lett, 1986, 79: 337-347

18 Nutman A P, Mojzsis S J, Friend C R L. Recognition of $\geqslant 3850 \mathrm{Ma}$ water-lain sediments in West Greenland and their significance for the early Archaean Earth. Geochim Cosmochim Acta, 1997, 61: 2475-2484

19 Bowring S A, Housh T B, Isachsen C E. The Acasta gneisses: Remnant of Earth's early crust. In: Newsom H E, Jones J H, eds. Origin of the Earth. New York: Oxford Univ Press, 1990. 319-343

20 Iizuka T, Horie K, Komiya T, et al. 4.2 Ga zircon xenocryst in Acasta gneiss from northwestern Canada: Evidence for early continental crust. Geology, 2006, 34: 245-248

21 Liu D Y, Nutman A P, Compston W, et al. Remnants of $3800 \mathrm{Ma}$ crust in the Chinese part of the Sino-Korean Craton. Geology, 1992, 20: 339-342

22 Song B, Nutman A P, Liu D Y, et al. 3800 to 2500 Ma crust in the Anshan area of Liaoning Provence, northeastern China. Precambrian Res, 1996, 78: 79-94

23 Wan Y S, Liu D Y, Song B, et al. Geochemical and Nd isotopic compositions of $3.8 \mathrm{Ga}$ meta-quartz diorite and trondhjemitie rocks from the Anshan area and their geological significance. J Asian Earth Sci, 2005, 24: 563-575

24 Black L P, Williams I S, Compston W. Four zircon ages from one rock: The history of a 3930 Ma old granulite from Mount Sones, Enderby Land, Antarctica. Contrib Mineral Petrol, 1986, 94: 427-437

25 Harley S L, Black L P. A revised Archean chronology for the Napier Complex, Enderby Land, from SHRIMP ion-microprobe studies. Antar Sci, 1997, 9: 74-91

26 Choi S H, Mukasa S B, Andronikov A V, et al. Lu-Hf systematics of the ultra-high temperature Napier Metamorphic Complex in Antarctica: Evidence for the early Archean differentiation of Earth's mantle. Earth Planet Sci Lett, 2006, 246: 305-316

27 Sano Y, Terada K, Hidaka H, et al. Palaeoproterozoic thermal events recorded in the $\sim 4.0$ Ga Acasta gneiss, Canada: Evidence from SHRIMP U-Pb dating of apatite and zircon. Geochim Cosmochim Acta, 1999, 63: 899-905

28 Wan Y S, Liu D Y, Dong C Y, et al. The oldest rocks and zircons in China (in Chinese). Acta Petrol Sin, 2009, 25: 1973-1807

29 Gebauer D, Williams I S, Compston W, et al. The development of the Central European Continental crust since the Early Archaean based on conventional and ion-microprobe dating of up to $3.84 \mathrm{Ga}$ old detrital zircons. Tectonophysics, 1989, 157: 81-96

30 Mueller P A, Wooden J L, Nutman A P, et al. Early Archean crust in the northern Wyoming province evidence from $\mathrm{U}-\mathrm{Pb}$ ages of detrital zircons. Precambrian Res, 1998, 91: 295-307

31 Wilde S A, Valley J W, Peck W H, et al. Evidence from detrital zircons for the existence of continental crust and oceans on the Earth 4.4 Ga ago. Nature, 2001, 409: 175-178

32 Hartmann L A, Endo I, Suita M T F, et al. Provenance and age delimitation of Quadrilátero Ferrífero sandstones based on zircon U-Pb isotopes. J South Am Earth Sci, 2006, 20: 273-285

33 Gehrels G E, DeCelles P G, Ojha T P, et al. Geologic and U-Pb geochronologic evidence for early Paleozoic tectonism in the Dadeldhura thrust sheet, far-west Nepal Himalaya. J Asian Earth Sci, 2006, 28: 385-408

34 Kröner A, Hegner E, Lehmann B, et al. Palaeozoic arc magmatism in the Central Asian Orogenic Belt of Kazakhstan: SHRIMP zircon ages and whole-rock Nd isotopic systematics. J Asian Earth Sci, 2008, 32: $118-130$

35 Wu F Y, Yang J H, Liu X M, et al. Nd isotopic constrains on crustal formation in the North China Craton. J Asian Earth Sci, 2005, 24: 523-545

36 Wilde $\mathrm{S}$ A, Valley $\mathrm{J} \mathrm{W}$, Kita $\mathrm{N} \mathrm{T}$, et al. SHRIMP U-Pb and CAMECA 1280 oxygen isotope results from ancient detrital zircons in the Caozhuang quartzite, eastern Hebei, North China Craton: Evidence for crustal reworking 3.8 Ga ago. Am J Sci, 2008, 308: 185199

37 Nutman A P, Wan Y S, Du L L, et al. Multistage late Neoarchaean crustal evolution of the North China Craton, eastern Hebei. Precambrian Res, 2011, 189: 43-65

38 Wen C Q, Duo J, Fan X P, et al. Detrital Zircon of 4100Ma in Quartzite in Burang, Tibet (in Chinese). Acta Geol Sin, 2006, 80: 
$1249-1251$

39 Duo J, Wen C Q, Guo J C, et al. 4.1 Ga old detrital zircon in western Tibet of China. Chin Sci Bull, 2007, 52: 23-26

40 Zhang S B, Zheng Y F, Wu Y B, et al. Zircon U-Pb age and Hf isotope evidence for $3.8 \mathrm{Ga}$ crustal remnant and episodeic reworking of Archean crust in South China. Earth Planet Sci Lett, 2006, 252: $56-71$

41 Wang H L, Chen L, Sun Y, et al. 4.1 Ga xenocrystal zircon from Ordovician volcanic rocks in western part of North Qinling Orogen. Chin Sci Bull, 2007, 52: 3002-3010

42 Diwu C R, Sun Y, Dong Z C, et al. In situ U-Pb geochronolory of Hadean zircon xenocryst (4.1-3.9 Ga) from western of the Northern Qinling Orogen (in Chinese). Acta Petrol Sin, 2010, 26: 1171-1174

43 Zheng J P, Griffin W L, Tang H Y, et al. Archean basement similar to the North China and Yangtze continents may be existed beneath the Western Cathaysia (in Chinese). Geoll J Chin Univ, 2008, 14: 549557

44 He S P, Li R S, Wang C, et al. Discovery of $\sim 4.0$ Ga detrital zircons in the Changdu Block, North Qiangtang, Tibetan Plateau. Chin Sci Bull, 2011, 56: 647-658

45 Chen B, Jahn B M. Genesis of post-collisional granitoids and basement nature of the Junggar Terrane, NW China: Nd-Sr isotope and trace element evidence. J Asian Earth Sci, 2004, 23: 691-703

46 Coleman R. Continental growth of Northwest China. Tectonics, 1989, 8: 621-625

47 Şengör A M C, Natal'in B A, Burtman V S. Evolution of the Altaid tectonic collage and Paleozoic crustal growth in Asia. Nature, 1993, 364: 299-307

48 Li J Y. Late Neoproterozoic and Paleozoic tectonic framework and evolutionof eastern Xinjiang, NW China (in Chinese). Geol Rev, 2004, 50: 304-322

49 Shu L S, Lu H F, Yin D H, et al. Late Paleozoic continental accretionary tectonics in Northern Xinjiang (in Chinese). Xinjiang Geol, 2001, 19: 59-63

50 Xiao W J, Han C M, Yuan C, et al. Middle Cambrian to Permian subduction-related accretionary orogenesis of North Xinjiang, NW China: Implications for the tectonic evolution of Central Asia. J Asian Earth Sci, 2008, 32: 102-117

51 Xiao W J, Windley B F, Yuan C, et al. Paleozoic multiple subduction-accretion processes of the southern Altaids. Am J Sci, 2009, 309: 221-270

52 Sun M, Long X P, Cai K D, et al. Early Paleozoic ridge subduction in the Chinese Altai: Insight from the abrupt change in zircon $\mathrm{Hf}$ isotopic compositions (in Chinese). Sci China Ser D-Earth Sci, 2009, 39: 935-948

53 Long X P, Yuan C, Sun M. Geochemistry and U-Pb detrital zircon dating of Paleozoic graywackes in East Junggar, NW China: Insights into subduction-accretion processes in the southern Central Asian Orogenic Belt. Gondwana Res, 2012, 21: 637-653

54 Wang H L, Xu X Y, He S P, et al. 1:1000000 Scale Geological Map of Tiansh and Its Adjacent Areas (in Chinese). Beijing: Geological Publishing House, 2007

55 He G Q, Li M S, Jia J D, et al. Significance of paleostruture and paleogeography of Ordovician-Silurian rock associations in Northern Xinjiang, China (in Chinese). Acta Sci Natur Univ Pekinensis, 2001, 37: $99-110$

56 Li J Y. Main characteristics and emplacement processes of the East Junggar ophiolites, Xinjiang China (in Chinese). Acta Petrol Sin, 1995, 11: 73-84

57 Niu H C, Zhang H Y, Shan Q, et al. Geochemistry of the Nb-enriched basalt and its significance in Zaheba ophiolite mélange (in Chinese). Acta Petrol Sin, 2009, 25: 916-924

58 Niu H C, Zhang H Y, Shan Q, et al. Discovery of super-silicic and super-titanic garnels in garnet-pyroxenite in Zaheba and its significance, eastern Junggar, NW, China. Chin Sci Bull, 2008, 53: 21862191

59 Niu H C, Shan Q, Zhang H Y, et al. ${ }^{40} \mathrm{Ar} /{ }^{39} \mathrm{Ar}$ geochronology of the ultrahigh-pressure metamorphic quartz-magnesitite in Zhaheba, eastern Junggar, Xinjiang (in Chinese). Acta Petrol Sin, 2007, 23:
$1627-1634$

60 Niu H C, Shan Q, Zhang B, et al. Discovery of garnet amphibolite in Zaheba ophiolitic mélange, eastern Junggar, NW, China (in Chinese). Acta Petrol Sin, 2009, 25: 1484-1491

61 Jian P, Liu D Y, Zhang Q, et al. SHRIMP dating of ophiolite and leucocrutic rocks within ophiolite (in Chinese). Front Earth Sci, 2003, 10: 439-456

62 Zhang Y Y, Guo Z J. New constraints on formation ages of ophiolites in northern Junggar and comparative study on their connection (in Chinese). Acta Petrol Sin, 2010, 26: 422-430

63 Xiao W J, Windley B F, Yan Q R, et al. SHRIMP zircon age of the Aermantai ophiolite in the North Xinjiang area, China and its tectonic implications (in Chinese). Acta Geol Sci, 2006, 80: 32-37

64 The Second Regional Geological Survey Team of Xinjiang Bureau of Geology and Mineral Resources. 1:50000 ScaleJialepakeyizengde and Tasikake Regional Geological Survey Report (in Chinese). 1995

65 Regional Geological Measuring Team of Xinjiang Geological Bureau and Institute of Geology. 1:200000 Scale Aoshenkeshan Regional Geological Survey Report (in Chinese). 1966

66 Regional Geological Measuring Team of Xinjiang Geological Bureau and Institute of Geology. 1:200000 Scale Kamosite Regional Geological Survey Report (in Chinese). 1976

67 Regional Geological Measuring Team of Xinjiang Geological Bureau and Institute of Geology. 1:200000 Scale Qiakuertu Country Regional Geological Survey Report (in Chinese). 1966

68 Sláma J, Košler J, Daniel J, et al. Plesovice zircon-A new natural reference material for $\mathrm{U}-\mathrm{Pb}$ and $\mathrm{Hf}$ isotopic microanalysis. Chem Geol, 2008, 249: 1-359

$69 \mathrm{Li} \mathrm{X} \mathrm{H,} \mathrm{Liu} \mathrm{Y,} \mathrm{Li} \mathrm{Q} \mathrm{L,} \mathrm{et} \mathrm{al.} \mathrm{Precise} \mathrm{determination} \mathrm{of} \mathrm{Phanerozoic}$ zircon $\mathrm{Pb} / \mathrm{Pb}$ ageby multicollector SIMS without external standardization. Geochem Geophys Geosyst, 2009, 10: Q04010

70 Andersen T. Correction of common $\mathrm{Pb}$ in $\mathrm{U}-\mathrm{Pb}$ analyses that do not report ${ }^{204} \mathrm{~Pb}$. Chem Geol, 2002, 192: 59-79

71 Ludwig K R. Isoplot 3.0-A geochronological toolkit for Microsoft Excel. Berkeley Geochron Cent, Spec Publ, 2003, 4: 70

72 Yuan H L, Gao S, Dai M N, et al. Simultaneous determinations of $\mathrm{U}-\mathrm{Pb}$ age, $\mathrm{Hf}$ isotopes and trace element compositions of zircon by excimer laser ablation quadrupole and multiple collector ICP-MS. Chem Geol, 2008, 247: 100-118

73 Bievre D P, Taylor P D. Table of the isotopic compositions of the elements. Int J Mass Spectrom Ion Process, 1993, 123: 149-166

74 Chu N C, Taylor R N, Chavagnac V, et al. Hf isotope ratio analysis using multi-collector inductively coupled plasma mass spectrometry: An evaluation of isobaric interference corrections. J Anal At Spectrom, 2002, 17: 1567-1574

75 Wu F Y, Yang Y H, Xie L W, et al. Hf isotopic compositions of the standard zircons and baddeleyites used in $\mathrm{U}-\mathrm{Pb}$ geochronology. Chem Geol, 2006, 234: 105-126

76 Elhlou S, Belousova E, Griffin W L, et al. Trace element and isotopic composition of GJ red zircon standard by laser ablation. Geochim Cosmochim Acta, 2006, 70(Suppl): A158

77 Scherer E, Munker C, Mezger K. Calibration of the lutetium-hafnium clock. Science, 2001, 293: 683-687

78 Blichert-Toft J, Albarède F. The Lu-Hf isotope geochemistry of chondrites and the evolution of the mantle-crust system. Earth Planet Sci Lett, 1997, 148: 243-258

79 Vervoort J D, Blichert-Toft J. Evolution of the depleted mantle: Hf isotope evidence from juvenile rocks through time. Geochim Cosmochim Acta, 1999, 63: 533-556

80 Griffin W L, Pearson N J, Belousova E. The Hf isotope composition of cratonic mantle: LAM-MC-ICPMS analysis of zircon megacrysts in kimberlites. Geochim Cosmochim Acta, 2000, 64: 133-147

81 Amelin Y, Lee D C, Halliday A N. Nature of the Earth's earliest crust from hafnium isotopes in single detrital zircons. Nature, 1999, 399: 252-255

82 Harrison T M, Blichert-Toft J, Muller W, et al. Heterogeneous Hadean hafnium: Evidence of continental crust at 4.4 to $4.5 \mathrm{Ga}$. Science, 2005, 310: 1947-1950

83 Wu F Y, Zhao G C, Wilde S A, et al. Nd isotopic constraints on 
crustal formation in the North China Craton. J Asian Earth Sci, 2005, 24: 523-545

84 Zhang Y, Liang G L, Qu X, et al. Evidence of U-Pb age and Hf isotope of zircons for Early Paleozoic magmatism in the Qiongheba arc, East Junggar (in Chinese). Acta Petrol Sin, 2010, 26: 2389-2398

85 Du S J, Qu X, Deng G, et al. Chronology and tectonic setting of the intrusive bodies and associated porphyry copper deposit in Hersai area, East Junggar (in Chinese). Acta Petrol Sin, 2010, 26: 29812996

86 Guo H C, Zhong L, Li L Q, et al. Zircon SHRIMP U-Pb dating of quartz diorite in the Koumenzi area, Karlik Mountains, East Tianshan, Xinjiang, China, and its geological significance (in Chinese). Geol Bull Chin, 2006, 25: 928-931

87 Cao F Y, Tu Q J, Zhang X M, et al. Preliminary determination of the Early Paleozoic magmatic arc in the Karlik Mountains, East Tianshan, and Xinjiang, China: Evidence from zircon SHRIMP U-Pb dating of granite bodies in the Tashuihe (in Chinese). Geol Bull Chin, 2006, 25: 923-927

88 Li J Y, Wang K Z, Sun G H, et al. Paleozoic active margin slices in the southern Turfan-Hami basin: geological records of subduction the Paleo-Asian Ocean plate in central Asian regions (in Chinese). Acta Petrol Sin, 2006, 22: 1087-1102

89 Sun M, Yuan C, Xiao W J, et al. Zircon U-Pb and Hf isotopic study of gneissic rocks from the Chinese Altai: Progressive accretionary history in the early to middle Paleozoic. Chem Geol, 2008, 247: 352383

90 Wang T, Hong D W, Jahn B, et al. Timing, petrogenesis and setting of Paleozoic synorogenic intrusions from the Altai Mountains, Northwest China: Implications for the tectonic evolution of an accretionary orogen. J Geol, 2006, 114: 735-751

91 Ceng Q S, Chen G H, Wang H, et al. Geochemical characteristic, SHRIMP zircon U-Pb and tectonic implication for granitoids in Chonghuer basin, Altai, Xinjiang (in Chinese). Acta Petrol Sin, 2007, 23: 1921-1932

92 Liu F, Li Y H, Mao J W, et al. SHRIMP U-Pb ages of the Abagong granites in the Altay Orogen and their geological implications (in Chinese). Acta Geosci Sin, 2007, 23: 1921-1932

93 Wong K, Sun M, Zhao G C, et al. Geochemical and geochronological studies of the Alegedayi ophiolitic complex and its implication for the evolution of the Chinese Altai. Gondwana Res, 2010, 18: 438-454

94 Cai F M, Dong L H, Yang F Q, et al. Age, geochemistry and petrogenesis of Tiemerte granites in the Kelang basin at the southern margin of Altai, Xinjiang (in Chinese). Acta Petrol Sin, 2007, 23: 1921-1932

95 Wang T, Tong Y, Li S, et al. Spatial and temporal variations of gran- itoids in the Altay Orogen and their implications for tectonic setting and crustal growth: perspectives from Chinese Altay (in Chinese). Acta Petrol Et Miner, 2010, 29: 595-618

96 Long X P, Yuan C, Sun M. Detrital zircon ages and Hf isotopes of the early Paleozoic flysch sequence in the Chinese Altai, NW China: New constrains on depositional age, provenance and tectonic evolution. Tectonophys, 2010, 480: 213-231

97 Cai K D, Sun M, Yuan C, et al. Prolonged magmatism, juvenile nature and tectonic evolution of the Chinese Altai, NW China: Evidence from zircon $\mathrm{U}-\mathrm{Pb}$ and $\mathrm{Hf}$ isotopic study of Paleozoic granitoids. J Asian Earth Sci, 2011, 42: 949-968

98 Wang Y J, Yuan C, Long X P, et al. Geochemistry, zircon U-Pb ages and $\mathrm{Hf}$ isotopes of the Paleozoic volcanic rocks in the northwestern Chinese Altai: Petrogenesis and tectonic implications. J Asian Earth Sci, 2011, 42: 969-985

99 Wang Y J, Liu H J, Zhou J P, et al. LA-ICP-MS U-Pb dating of detrital zircons from the marine volcanic-sedimentary rocks in the northern Kamste, Eastern Junggar and its geological significance (in Chinese). Geoscience, 2011, 25: 1047-1058

100 Li Y P, Li J Y, Sun G H, et al. Basement of Junggar basin: Evidence from detrital zircons in sandstone of previous Devonian Kalamaili formation (in Chinese). Acta Petrol Sin, 2007, 23: 1577-1590

101 Huang G, Niu G Z, Wang X L, et al. Formation and emplacement age of Karamaili ophiolite: LA-ICP-MS zircon U-Pb age evidence from the diabase and tuff in eastern Junggar, Xinjiang (in Chinese). Geol Bull Chin, 2012, 31: 1267-1278

102 Li J Y, He G Q, Xu X, et al. Crustal tectonic framework of Northern Xinjiang and adjacent regions and its formation (in Chinese). Acta Geol Sin, 2006, 80: 148-167

103 Jiang Y J, Yang B Z, Wang Y Y, et al. Structural feature and evolution in northeast part of Junggar basin (in Chinese). Acta Geol Sin, 2002, 76: 462-468

104 Li H O, Jiang M, Wang Y J, et al. Image of crust and upper mantle structure along the array from Fuyun to Kuerle by P-to-S converted waves (in Chinese). Acta Geol Sin, 2006, 80: 135-141

105 Wang Y J, Qian R Y, Jiang M, et al. Image of crust and upper mantle velocity structure along the array from Fuyun to Kuerle by seismic tomography (in Chinese). Acta Geol Sin, 2006, 80: 142-147

106 Su Y Z. On the geological and geographical distribution of Tuvaella with reference to its habitat (in Chinese). Acta Palaeont Sin, 1981, 20: $567-576$

107 Zhang Z X, Rong J Y, Di Q L. Silurian Tuvaella gigantean faunule of the Barkol area, Northeastern Xinjiang (in Chinese). Acta Palaeont Sin, 1983, 22: 278-294

Open Access This article is distributed under the terms of the Creative Commons Attribution License which permits any use, distribution, and reproduction in any medium, provided the original author(s) and source are credited. 